\title{
Role of Reactive Oxygen Species in Cancer Progression: Molecular Mechanisms and Recent Advancements
}

\author{
Vaishali Aggarwal ${ }^{1}$, Hardeep Singh Tuli ${ }^{2, *}$, Ayșegül Varol ${ }^{3}$, Falak Thakral ${ }^{2}$, \\ Mukerrem Betul Yerer ${ }^{4}\left({ }^{\oplus}\right.$, Katrin Sak ${ }^{5}{ }^{\circledR}$, Mehmet Varol ${ }^{6}{ }^{\circ}$, Aklank Jain ${ }^{7}{ }^{\circ}$,
}

Md. Asaduzzaman Khan ${ }^{8(1)}$ and Gautam Sethi ${ }^{9, *}$

1 Department of Histopathology, Post Graduate Institute of Medical Education and Research (PGIMER), Punjab, Chandigarh 160012, India; vaishali.pgi@gmail.com

2 Department of Biotechnology, Maharishi Markandeshwar (Deemed to be University), Mullana, Ambala, Haryana 133207, India; thakralfalak@gmail.com

3 Department of Pharmacology, Faculty of Pharmacy, Anadolu University, Eskişehir TR26470, Turkey; aysegulv@anadolu.edu.tr

4 Department of Pharmacology, Faculty of Pharmacy, Erciyes University, Kayseri 38039, Turkey; eczbetul@yahoo.com

$5 \quad$ NGO Praeventio, Tartu 50407, Estonia; katrin.sak.001@mail.ee

6 Department of Molecular Biology and Genetics, Faculty of Science, Kotekli Campus, Mugla Sitki Kocman University, Mugla TR48000, Turkey; mehmetvarol@mu.edu.tr

7 Department of Animal Sciences, Central University of Punjab, City Campus, Mansa Road, Bathinda 151001, India; aklankjain@gmail.com

8 The Research Center for Preclinical Medicine, Southwest Medical University, Luzhou 646000, Sichuan, China; asadkhan@swmu.edu.cn

9 Department of Pharmacology, Yong Loo Lin School of Medicine, National University of Singapore, Singapore 117600, Singapore

* Correspondence: hardeep.biotech@gmail.com (H.S.T.); phcgs@nus.edu.sg (G.S.); Tel.: +91-9896619923 (H.S.T.); +65-6516-3267 (G.S.)

Received: 24 October 2019; Accepted: 12 November 2019; Published: 13 November 2019

\begin{abstract}
Reactive oxygen species (ROS) play a pivotal role in biological processes and continuous ROS production in normal cells is controlled by the appropriate regulation between the silver lining of low and high ROS concentration mediated effects. Interestingly, ROS also dynamically influences the tumor microenvironment and is known to initiate cancer angiogenesis, metastasis, and survival at different concentrations. At moderate concentration, ROS activates the cancer cell survival signaling cascade involving mitogen-activated protein kinase/extracellular signal-regulated protein kinases $1 / 2$ (MAPK/ERK1/2), p38, c-Jun N-terminal kinase (JNK), and phosphoinositide-3-kinase/ protein kinase $\mathrm{B}$ (PI3K/Akt), which in turn activate the nuclear factor kappa-light-chain-enhancer of activated B cells (NF-KB), matrix metalloproteinases (MMPs), and vascular endothelial growth factor (VEGF). At high concentrations, ROS can cause cancer cell apoptosis. Hence, it critically depends upon the ROS levels, to either augment tumorigenesis or lead to apoptosis. The major issue is targeting the dual actions of ROS effectively with respect to the concentration bias, which needs to be monitored carefully to impede tumor angiogenesis and metastasis for ROS to serve as potential therapeutic targets exogenously/endogenously. Overall, additional research is required to comprehend the potential of ROS as an effective anti-tumor modality and therapeutic target for treating malignancies.
\end{abstract}

Keywords: reactive oxygen species (ROS); oxidative stress; inflammation; angiogenesis; metastasis; miRNA 


\section{Introduction}

Despite continuous efforts in the development of novel treatment modalities, cancer still remains one of the most dreadful diseases in both developed and, developing countries; being an indomitable conundrum for scientists worldwide. Based on the recently published GLOBOCAN 2018 report, there was a prediction of 18.1 million new cancer cases and 9.6 million cases with cancer mortality in women and men. If the industrial development accompanied by environmental pollution and alterations in the human lifestyle, continue as fast as hitherto, predictions suggest by 2030, almost 13 million people will die from different cancers each year [1]. This would be a huge burden to the whole society and needs urgent intervention at different levels, including not only scientific contribution but also political statutes in implementation of diverse preventive measures.

The complexity of cancer is attributed to its multifaceted and multifactorial presentation. In the past few decades, the disruption of redox balance has been illustrated to be one of the most important reasons underlying cancer development, its progression, and metastasis in human cells [2]. This disproportionality in redox homeostasis is documented to be induced via increased free radicals, predominantly ROS. These highly active radicals originate from both intrinsic and extrinsic sources. Intrinsic sources of ROS mostly include mitochondria, inflammatory cells, and several enzymatic cellular complexes; extrinsic sources of ROS include pro-oxidant environmental toxins, radiation, [3] and diverse chemical compounds, including alcohol, tobacco smoking, and certain drugs [4]. Such free radicals can cause damage to various important biomolecules, including lipids, proteins, and nucleic acids, leading to oxidative stress and damaging different human tissues.

Elevated ROS levels, accompanied with down-regulation of cellular antioxidant enzyme systems, result in malignant transformation via different molecular targets, such as NF- $\mathrm{KB}$ and nuclear factor (erythroid-derived 2)-like-2 factor (Nrf2) [5,6]. Signaling cascades regulated by these key factors generate an inflammatory environment leading to the suppression of apoptotic cell death, tumor proliferation, angiogenesis, and metastasis; which cumulatively augment initiation, development, and progression of malignant neoplasms (Table 1). This review article summarizes the present up-to-date knowledge of the molecular mechanisms of ROS generation, its role in tumor growth and metastasis, along with highlighting the potential targets of the ROS cascade for potential therapeutic strategies.

Table 1. Role of ROS in cancer progression.

\begin{tabular}{|c|c|c|c|}
\hline Effect & Mechanism & Cell Line & References \\
\hline \multirow[t]{3}{*}{$\begin{array}{l}\text { Oxidative } \\
\text { Stress }\end{array}$} & $\begin{array}{l}\text { Aquaporin AQP5-mediated } \mathrm{H}_{2} \mathrm{O}_{2} \text { influx rate indicates the } \\
\text { presence of a highly efficient peroxiporin activity and } \\
\text { consequently activates signaling networks related to cell } \\
\text { survival and cancer progression }\end{array}$ & $\begin{array}{l}\text { Pancreatic } \\
\text { Carcinoma line-3 } \\
\text { (BxPC3) }\end{array}$ & [7] \\
\hline & $\begin{array}{l}\text { PCB118 promotes hepatocellular carcinoma cell (HCC) } \\
\text { proliferation via Pyruvate kinase M2 (PKM2)-dependent } \\
\text { up-regulation of glycolysis, which is mediated by Aryl } \\
\text { hydrocarbon receptor/Nicotinamide adenine dinucleotide } \\
\text { phosphate oxidase (AhR/NADPH oxidase)-induced } \\
\text { ROS prouction }\end{array}$ & SMMC-7721 & [8] \\
\hline & $\begin{array}{l}\text { Enhanced ROS of exposed cells alters the mitochondrial } \\
\text { metabolic activities in terms of increased mitochondrial mass } \\
\text { and DNA content and initiates cancer progression through } \\
\text { modifying cellar biomarkers }\end{array}$ & MOE1A & [9] \\
\hline \multirow[t]{2}{*}{$\begin{array}{l}\text { Inflammatory } \\
\text { markers }\end{array}$} & $\begin{array}{l}\text { Serum ROS and damaged mtDNA may be markers of } \\
\text { mitochondrial metabolism through oxygenation of the } \\
\text { primary tumor and results in systemic inflammation and } \\
\text { adverse outcomes of locally advanced rectal cancer (LARC) }\end{array}$ & $\begin{array}{l}\text { HCT-116, HT-29, and } \\
\text { LoVo }\end{array}$ & [10] \\
\hline & $\begin{array}{l}\text { Inflammation in the stroma induces TNF- } \alpha \text { signaling and the } \\
\text { NOX1/ROS signaling pathway is activated downstream with } \\
\text { expression of TLR2 which is an important tumor-promoting } \\
\text { mechanism stimulated by inflammation }\end{array}$ & Mouse Model & [11] \\
\hline
\end{tabular}


Table 1. Cont.

\begin{tabular}{|c|c|c|c|}
\hline Effect & Mechanism & Cell Line & References \\
\hline & $\begin{array}{l}\text { Alkylating agents may evoke inflammatory responses that } \\
\text { seem to contribute to malignant progression in specific breast } \\
\text { cancer cells }\end{array}$ & $\begin{array}{l}\text { MDA-MB231, } \\
\text { Hs578T, SKBR3 and } \\
\text { MCF7 }\end{array}$ & [12] \\
\hline \multirow[t]{4}{*}{ Metastasis } & $\begin{array}{l}\text { ROS induce epithelial-mesenchymal transition (EMT), the } \\
\text { glycolytic switch, and mitochondrial repression by activating } \\
\text { the Distal-less homeobox-2 (Dlx-2)/Snail axis, thereby playing } \\
\text { crucial roles in metastasis }\end{array}$ & MCF-7 & [13] \\
\hline & $\begin{array}{l}\text { Elevated mitochondrial ROS via fatty acid } \beta \text {-oxidation, } \\
\text { activates the MAPK cascades, results in EMT process of ROS } \\
\text { high tumor spheres (RH-TS) cells, and enhances metastasis }\end{array}$ & $\begin{array}{l}4 \mathrm{~T} 1, \mathrm{SW} 480, \mathrm{HCT} 116 \\
\text { and HT29 }\end{array}$ & [14] \\
\hline & $\begin{array}{l}\text { Loss of TMEM126A induces ROS production with } \\
\text { mitochondrial dysfunction and subsequently metastasis by } \\
\text { activating extracellular matrix (ECM) remodeling and EMT }\end{array}$ & MDA-MB-231HM & [15] \\
\hline & $\begin{array}{l}\text { PM2.5 exposure induces ROS, which activates loc } 146880 \\
\text { expression and promotes the malignant behavior }\end{array}$ & A549 & [16] \\
\hline \multirow[t]{3}{*}{ Angiogenesis } & $\begin{array}{l}\text { ROS-ERK } 1 / 2-H I F-1 \alpha \text {-VEGF-induces angiogenesis by } \\
\text { increased level of RRM2 }\end{array}$ & C33A and MCF-7 & [17] \\
\hline & $\begin{array}{l}\text { High glucose increases angiogenesis and decreases apoptosis } \\
\text { due to activation of the NF- } \mathrm{kB} \text { pathway by increasing ROS }\end{array}$ & MCF-7 & [18] \\
\hline & $\begin{array}{l}\text { 27-Hydroxycholesterol (27HC) enhanced the generation of } \\
\text { ROS and activates the STAT-3/VEGF signaling in an ER } \\
\text { independent manner which results in induced angiogenesis }\end{array}$ & Breast Cancer Cells & [19] \\
\hline
\end{tabular}

\section{Role of ROS in Cancer Progression}

\subsection{ROS-Mediated Induction of Oxidative Stress}

Oxygen is a multifaceted molecule, which is crucial for life sustainability but can be harmful when it is converted to ROS through oxidation-reduction reactions. The distinct aspect of ROS was first identified by Gerschmann in 1954 [20,21] and its free radical potential was described by Denham Harman in the free radical theory of aging in 1956 [21,22]. This initial work from the group; steadily triggered further investigations in the dimension of ROS to decipher their precise role in biological systems [21]. The discovery of the first described antioxidant enzyme, superoxide dismutase (SOD), by McCord [21,23] postulated the instrumental role of ROS through free radical generation. Following the initial studies on the substantial potential role of ROS, the focus shifted to delineate the beneficial and harmful effects of ROS in numerous pathological and physiological processes and their mechanism of action.

In a normal cell, ROS levels are balanced through numerous detoxification processes regulated through antioxidant enzymes. Hence, ROS homeostasis is well sustained, which contributes to the maintenance of redox balance in healthy cells. The complex I and III of the mitochondrial respiratory chain under high membrane potential, are contemplated to be the point of origin of ROS particularly, but numerous other resources may also play a pivotal role in elevated ROS generations, such as $\alpha$-ketoglutarate dehydrogenase, monoamine oxidase, mitochondrial $\mathrm{p} 66^{\text {Shc }}$, sirtuins, Nrf2, and forkhead box $\mathrm{O} 3$ (FOXO3) besides the underlying redox cycling reactions [24]. This elevated ROS production or defective defense mechanism may also lead to elevated oxidative stress levels leading to diverse pathological conditions. Examples of endogenous sources of ROS include mitochondrial oxidative phosphorylation, p450 metabolism, peroxisomes, and from the activation of inflammatory cells such as macrophages and neutrophils. It is thought that during the mitochondrial respiratory process, $1-2 \%$ of molecular oxygen is converted to ROS through one to three electron reductions and this leads to the formation of hydroxyl, hydrogen peroxide, superoxide, and peroxynitrite radicals [25].

Oxidative stress is one of the main leading causes of toxicity which is attributed to the interactions of ROS as well as reactive nitrogen species (RNS) with cellular macromolecules such as DNA, lipid, and proteins, which interfere with the signal transduction pathways such as protein kinases, phosphatases, and transduction mechanisms (Figure 1). The pathological consequences of oxidative stress are 
characterized by impaired glucose tolerance due to mitochondrial oxidative stress. This is attributed to pro-oxidants changing their thiol/disulphide redox state which leads to diabetes mellitus and cancer or through the augmented action of either $\mathrm{NAD}(\mathrm{P}) \mathrm{H}$ oxidase leading to inflammatory oxidative conditions which is associated with chronic inflammation and atherosclerosis or through the action of xanthine oxidase-induced ROS formation which has been associated with reperfusion injury and ischemia [21]. Further, the ageing process can be attributed to the detrimental magnitude of free radicals leading to DNA damage, lipid peroxidation, and protein oxidation [21,22].

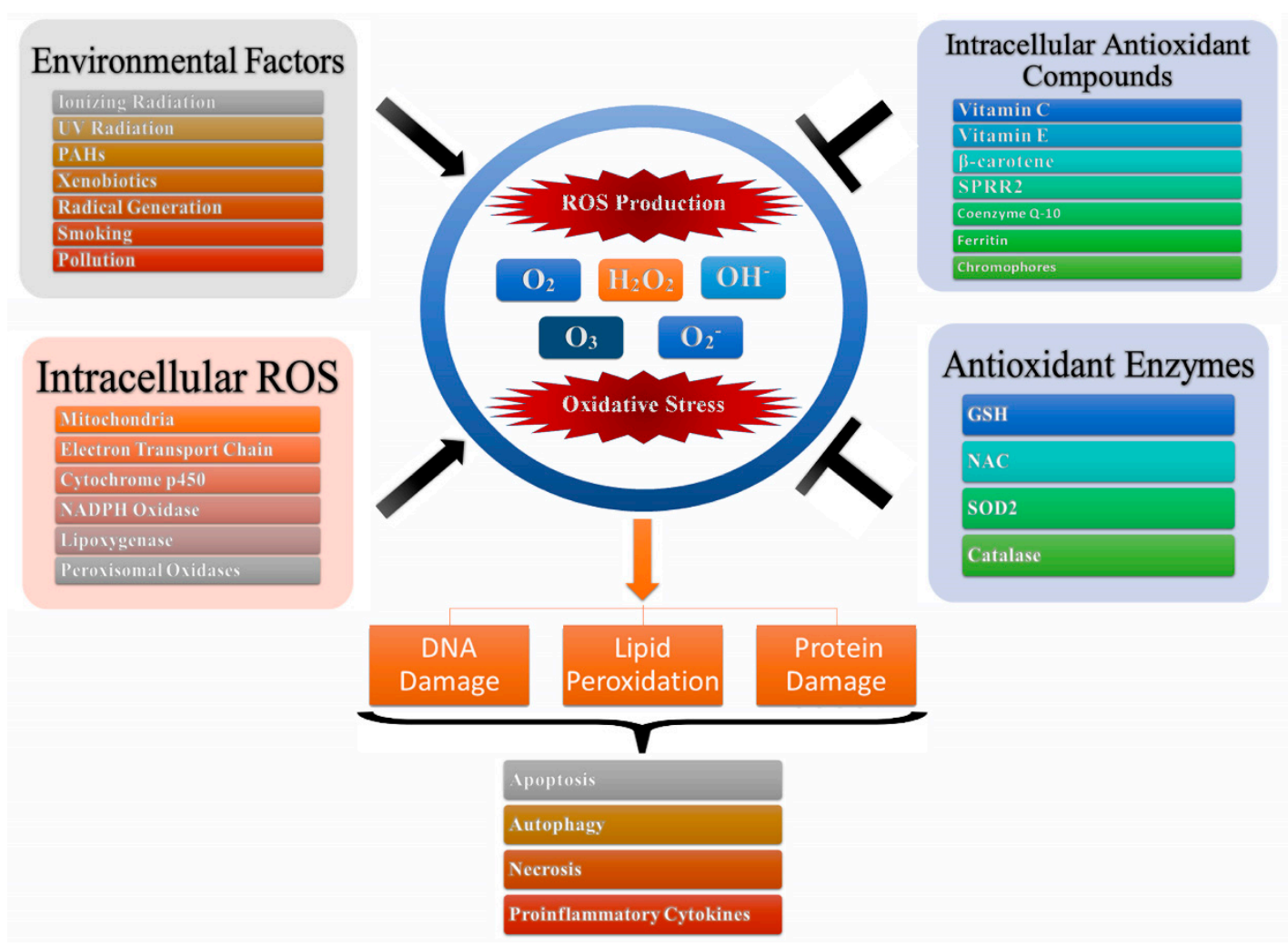

Figure 1. Oxidative stress and production of reactive oxygen species. Intracellular ROS and environmental factors (exogenous ROS) initiates ROS production leading to oxidative stress which in turn leads to DNA/lipid/protein degradation resulting in apoptosis, autophagy, necrosis and production of pro-inflammatory cytokines.

The connotation of oxidative and nitrosative stress with chronic and acute disease presentation is based on the biomarkers validated for oxidative stress. In an excellent review by Dalle-Donne and coworkers [21,26], the group summarized the biomarkers of oxidative stress and their correlation with human disease presentation. Natural antioxidants can protect the cell via scavenging the ROS. They may be separated into three classes — endogenous antioxidants (bilirubin, catalase (CAT), ferritin, SOD, glutathione, coenzyme Q, l-carnitine, alpha lipoic acid, glutathione peroxidase (GPx), melatonin, metallothionein, thioredoxins, peroxiredoxins, and uric acid), natural antioxidants (ascorbic acid, polyphenol metabolites, $\beta$-carotene, vitamin $\mathrm{E}$, and vitamin $\mathrm{A}$ ), and synthetic antioxidants (Nrf2, tiron, pyruvate, selenium, and $\mathrm{N}$-acetyl cysteine (NAC)). Protecting the organism against harmful oxidants is a complex interaction between these antioxidants. High intracellular ROS concentration is important for damage, but another important fact is the equilibrium between ROS and antioxidant systems. The ROS production/antioxidant defense system balance is required for homeostasis [25]. Under normal conditions antioxidants outbalance oxidants but under oxidative conditions pro-oxidants prevail antioxidants [27]. 


\subsection{Inflammatory Markers and ROS}

The intricate relationship between cancer and, prolonged inflammation has been thoroughly investigated since Virchow's hypothesis [28]. In 1863, Rudolf Virchow propounded that the "lymphoreticular infiltrate" reflected the origin of cancer at the locations of chronic inflammation [29]. The obtained epidemiological and experimental data from the numerous studies supported Virchow's hypothesis and revealed that inflammatory processes regulate the course of cancer based on the level of inflammation-related factors, inflammatory cytokines, and chemokines, in the tumor microenvironment, either by producing an antitumor response or by inducing cell transformation and malignancy [30-32]. One of the major regulatory components in the relationship between cancer and chronic inflammation is ROS that has an ability to affect the type, presence, and levels of inflammation-modulating factors such as activator protein 1 (AP-1), $\beta$-catenin/Wnt (wingless related integration site), HIF- $1 \alpha$ (hypoxia-inducible factor-1 alpha), NF-kB, PPAR- $\gamma$ (peroxisome proliferator-activated receptor gamma), p53, inflammatory cytokines, chemokines, and growth factors [27,33-35]. However, it should be noted that there is a complex crosstalk between chronic inflammation, ROS accumulation, and cancer progression (Figure 2). The inflammatory cells in the tumor microenvironment lead to a massive production of ROS by activating the oxidant-generating enzymes such as inducible nitric oxide synthase (iNOS), myeloperoxidase (MPO), NADPH oxidase, and xanthine oxidase (XO), and by up-regulating cyclooxygenase 2 (COX2) and lipoxygenase (LOX) to remove and disrupt the biological, chemical, and physical factors. The abundant accumulation of ROS also produces oxidative damage to the DNA, RNA, proteins, lipids, and mitochondria.

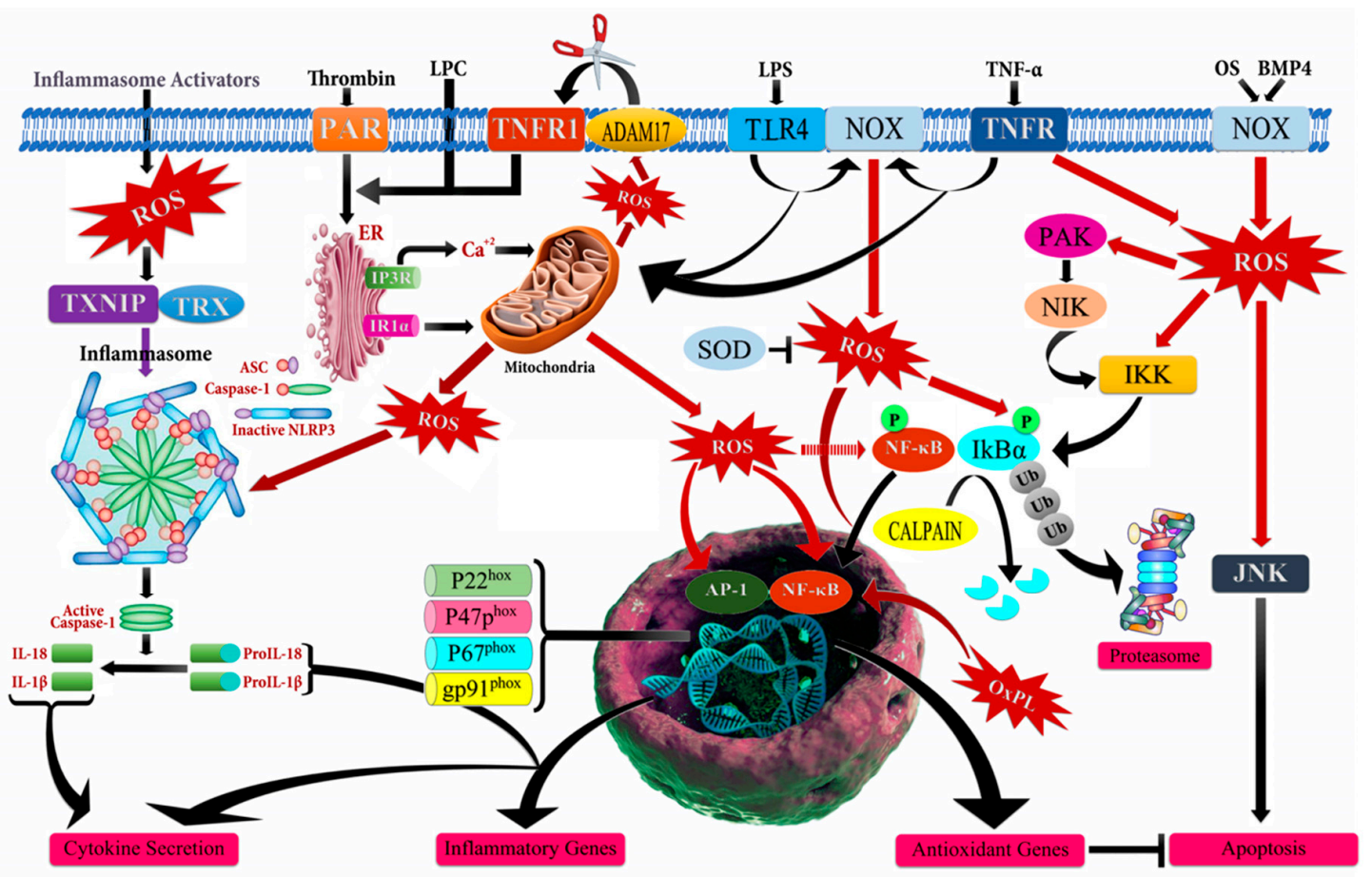

Figure 2. Schematic illustration of mechanism of action of reactive oxygen species (ROS) leading to inflammation. ADAM17 (ADAM metallopeptidase domain 17); ASC (Activating signal co-integrator 1); BMP4 (Bone morphogenetic protein 4); IKB- $\alpha$ (Inhibitor of nuclear factor kappa B kinase regulatory subunit alpha); IKK (Inhibitor of nuclear factor kappa-B kinase); IP3R (Inositol 1,4,5-trisphosphate receptor type 3); JNK (c-Jun N-terminal kinase); LPC (Lysophosphatidylcholine); LPS (Lipopolysaccharide); NF-kB (Nuclear factor kappa subunit B); NLRP3 (NLR family pyrin domain containing 3); NOX (NADPH oxidase); OxPL (Oxidized phospholipids); PAR (Par family cell polarity regulator); PAK (p21 (RAC1) activated kinase); SOD (Superoxide dismutase); TLR4 (Toll like receptor 4); TNF- $\alpha$ (Tumor necrosis factor alpha); TNFR (TNF receptor superfamily); TNFR1 (TNF receptor superfamily 1); TXNIP (Thioredoxin interacting protein); Ub (Ubiquitin). 
This causes an increased mutation load, defects in signal-transduction, inactivation of apoptosis, and overpowered generation of additional ROS that activate the inflammation-modulating factors, inflammatory cytokines, and chemokines [34-37]. Apart from the induction of chronic inflammation by ROS-mediated NF- $\mathrm{kB}$ activation, the active NF- $\mathrm{kB}$ is considered to be a key component in the rise of therapy-resistant cancers toward fractional gamma-irradiation therapy and chemotherapeutic agents such as 5-fluorouracil, bortezomib, cisplatin, daunorubicin, doxorubicin, paclitaxel, vinblastine, vincristine, and tamoxifen, through the transcriptional up-regulation of Akt, Bcl-2 (B-cell lymphoma 2), Bcl-xL (B-cell lymphoma- extra-large), cyclin D1, COX-2, survivin, and XIAP (X-linked inhibitor of apoptosis) [38-43]. Targeting ROS consequently seems to be a very promising way to modulate cancer related chronic inflammation and the hallmarks for cancer development such as sustaining proliferative signaling, evading growth suppressors, activating invasion and metastasis, enabling replicative immortality, inducing angiogenesis, and resisting cell death [37,44].

\subsection{Cancer Metastasis and ROS}

Metastasis involves the spread of cancer cells from the primary tumor to the surrounding tissues and to distant organs, and is the primary cause of morbidity and mortality [45]. Studies reveal that tumor metastasis is not an autonomous program but a complex and multifaceted event, occurring due to the intrinsic mutational burden of cancerous cells and bidirectional interaction between nonmalignant and malignant cells [46]. It occurs due to the up-regulation of several transcriptional factors such as NF-kB, ETS-1 (ETS proto-oncogene 1, transcription factor), Twist, Snail, AP-1, and Zeb (zinc finger E-box binding homeobox); metalloproteases viz. MMP-9 and, MMP-2; and chemokines or cytokines like transforming growth factor beta (TGF- $\beta$ ) (Figure 3) [47]. ROS plays an important role in the migration and invasion of cancerous cells. ROS are mainly produced as byproducts during mitochondrial electron transport in aerobic respiration and have numerous deleterious effects [48]. Epithelial to mesenchymal transition (EMT) is the major cause of tumor metastasis, where epithelial cells lose their polarity, cell-cell adhesion, and gain mobility.

Several studies have proved ROS to be a major cause of EMT. TGF- $\beta 1$ regulates uPA (Urokinase type Plasminogen Activator) and MMP-9 to facilitate cell migration and invasion through ROS-dependent mechanisms [49]. Another study revealed that ROS increases tumor migration by inducing hypoxia mediated MMPs and, cathepsin expression [50,51]. According to a study reported by Zhang, NADPH oxidase 4 (NOX4)-dependent ROS production is necessary for TGF $\beta 1$-induced EMT in MDAMB-231C and MCG-10A cell lines [52]. P53 also plays a major role in cell migration using cytokines TGF $\beta 1$. Pelicano et al. suggested that mitochondrial dysfunction can lead to increased ROS production, which further up-regulates C-X-C motif chemokine 14 (CXCL14) expression through the AP-1 signaling pathway and, enhances cell mobility by elevating cytosolic $\mathrm{Ca}^{2+}$ levels [53]. ROS activate Nrf2 that stimulates Klf9 (Krupple like factor 9), thus activating ERK1/2; and results in an increased ROS production in cancer cells. Thus, a premalignant growth can be suppressed by using topical antioxidants that target Klf9 [54,55].

Mitochondrial $\mathrm{Ca}^{2+}$ also plays an important role in cancer metastasis. Jin and his colleagues observed that MCUR1 (Mitochondrial Calcium Uniporter Regulator 1) is up-regulated in hepatocellular carcinoma (HCC) which promotes EMT by activating ROS/Notch1/Nrf2 pathways. Thus, MCUR1 can be a potential target for the treatment of HCC [56]. Aydin et al. analyzed that NOX2 generates ROS, which influence metastasis by down-modulating the function of natural killer (NK) cells, and its inhibition can restore the IFN $\gamma$ (interferon gamma)-dependent NK cell-mediated clearance of myeloma cells [57]. Vimentin protein also plays a major role in cancer initiation and progression such as EMT, and metastasis. Oxidative stress caused by HIF-1 regulates vimentin gene transcription, which helps in the formation of invadopodia during cancer cell invasion and migration [58]. Inhibition of vimentin expression by RNAi can reduce cell metastasis and hence decrease tumor volume [59]. ROS also induces epigenetic changes in the promoter region of E-cadherin and various other tumor suppressor genes, hence leading to tumor progression and metastasis. It causes hyper-methylation of 
the promoter gene by increasing Snail expression. Snail induces DNA methylation with the help of histone deacetylase 1 (HDAC1) and DNA methyltransferase 1 (DNMT1) [60].

\subsection{Angiogenesis and ROS}

During the initial stages of tumorigenesis, new blood vessels are formed from the pre-existing vasculatures, a process known as angiogenesis, which supports tumor proliferation and survival [61-64]. ROS-dependent angiogenesis is initiated through cancer proliferation, which in turn increases the metabolic rate leading to the generation of high ROS levels $[63,64]$. These elevated ROS levels lead to oxidative stress in the tumor microenvironment, which initiates secretion of angiogenic modulators [65]. Both endogenous and exogenous ROS spearheads stimulation of growth factors, cytokines, and transcription factors like VEGF and HiF-1 $\alpha$, which promote tumor migration and proliferation through ROS-dependent cellular signaling $[62,65,66]$. The signaling cascade through ROS mediation has been documented to perpetuate VEGF secretion and activate the PI3K/Akt/mammalian target of the rapamycin (mTOR) pathway through hypoxia independent or dependent mechanisms (through stabilization of HIF- $1 \alpha$ which increases production of VEGF) (Figure 4), [67]. Additionally, the Ras signaling pathway has also been reported to up-regulate VEGF secretion [68]. Recently, mutant p53 was also recognized to modulate the angiogenic response in tumor proliferation through the ROS-mediated activation of VEGF-A and HiF-1 in HCT116 human colon carcinoma cells [69]. The mechanism of ROS-mediated angiogenesis has been extensively studied to understand the signaling cascade modulating cancer progression. In a study carried out using MDA-MB-231 breast cancer cells, deferoxamine (DFO) induced HIF- $1 \alpha$ through ERK1/2 phosphorylation which promoted tumor migration and metastasis [70].

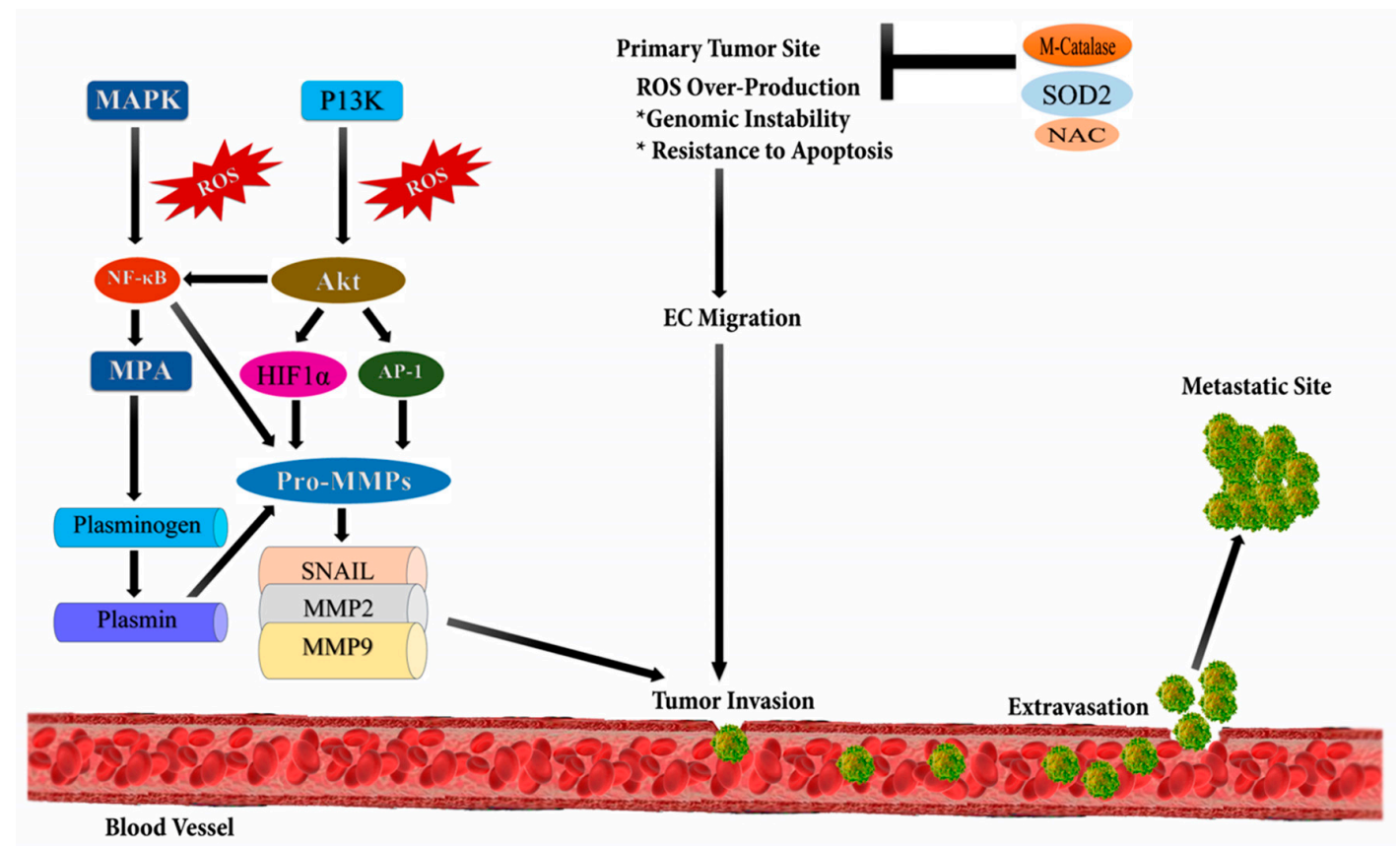

Figure 3. Reactive oxygen species and metastasis. High levels of reactive oxygen species leads to metastasis through the stimulation of phosphoinositide-3-kinase regulatory subunit/AKT serine/threonine kinases/mechanistic target of rapamycin kinase (PI3K/Akt/mTOR), and MAPK (Mitogen-activated protein kinases) signaling pathways which activates downstream SNAIL, MMP2 (metalloproteinase 2), and MMP9 (metalloproteinase 9) enzymes initiating epithelial-mesenchymal transition (EMT) leading to metastasis. 


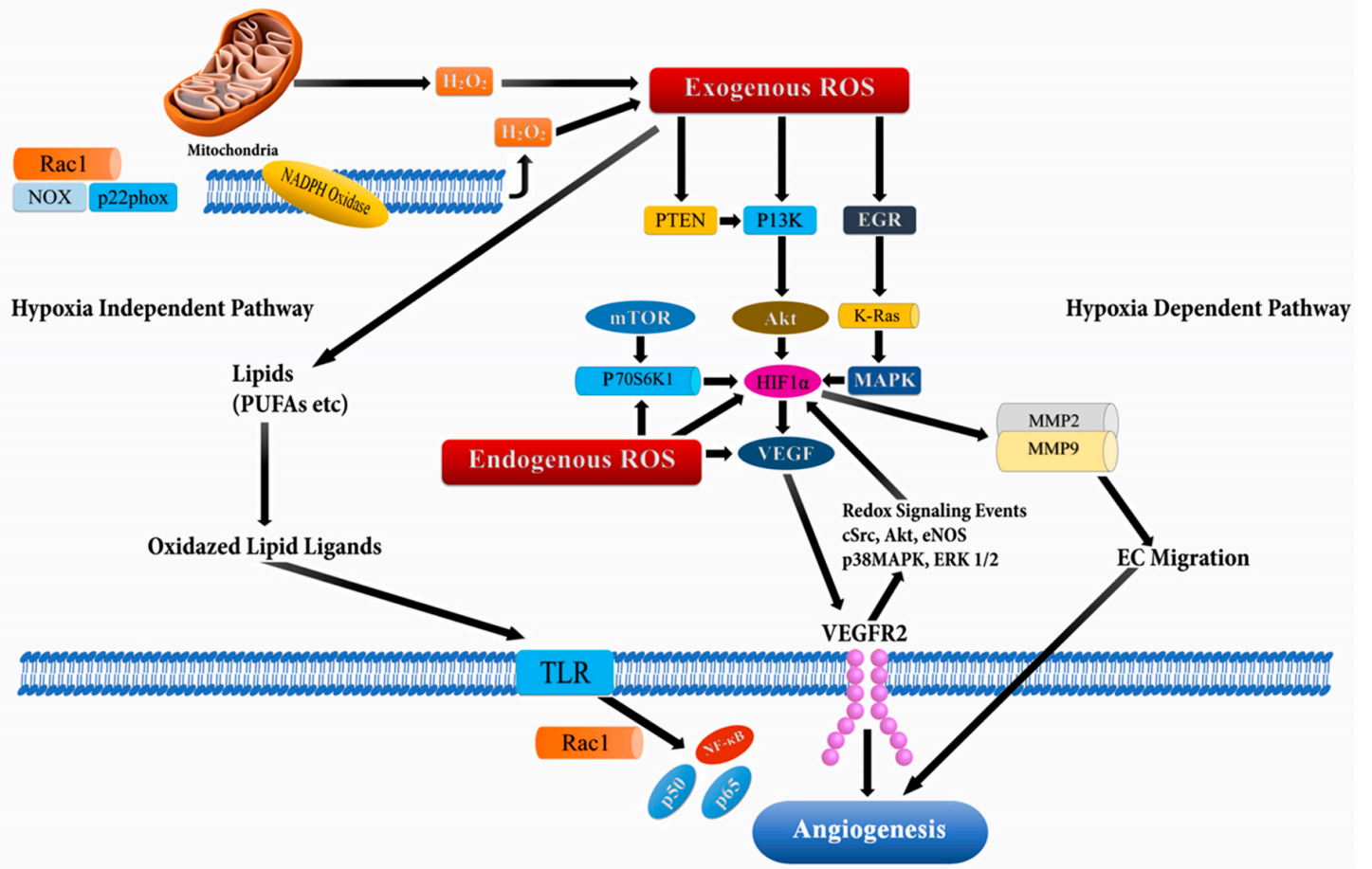

Figure 4. Angiogenesis activation through reactive oxygen species (ROS) via hypoxia dependent and hypoxia independent pathways. The hypoxia dependent pathway increases vascular endothelial growth factor (VEGF) expression via the phosphoinositide-3-kinase regulatory subunit/AKT serine/threonine kinases/mechanistic target of rapamycin kinase (PI3K/Akt/mTOR), PTEN (phosphatase and tensin homolog), and MAPK (Mitogen-activated protein kinases) signaling cascades via HIF-1 $\alpha$ (Hypoxia-inducible factor1-alpha) and p70S6K1 (ribosomal protein S6 kinase B1), which release various cytokines, growth factors, and up-regulation of MMPs (matrix metalloproteinases) leading to angiogenesis. The hypoxia independent pathway leads to angiogenesis through oxidative lipid ligands which activates NF-kB (Nuclear factor kappa subunit B) via Toll-like receptors (TLRs).

Han and colleagues demonstrated that the elevated levels of epidermal growth factor (EGF) triggered hydrogen peroxide production, which stimulated p70S6K1 via the PI3K/Akt signaling pathway, leading to the activation of downstream VEGF and HiF-1 $\alpha$ [71]. On similar lines, Liu et al. reported that EGF lead to increased production of hydrogen peroxide in OVCAR-3 ovarian cancer cells, which activated the AKT/p70S6K1 pathway, thereby resulting in increased VEGF expression [72]. The group further documented that catalase overexpression and rapamycin inhibited angiogenesis. Hydrogen peroxide was also illustrated to inactivate phosphatase and tension homolog (PTEN) through the reversible oxidation of phosphatases in the cysteine thiol group and promote activation of the PI3K/Akt/mTORsignaling cascade and Ras [73].

In another study on ovarian cancer cells, Xia and colleagues documented that NOX4 knockdown lead to a reduction of VEGF and HIF- $1 \alpha$, which in turn regulated tumor angiogenesis [74,75]. A similar mechanism of action of ROS was illustrated through experiments in WM35 melanoma cells, where Akt induced the expression of NOX4 [75,76]. NADPH oxidase 2 (Nox2)-derived ROS was also reported to induce cancer progression and migration, modulated through the ERK/PI3K/AKT/Src (Proto-oncogene tyrosine -protein kinase)-dependent pathway leading to the activation of endothelial cells and induction of angiogenesis [77-79]. Nox1 (NADPH oxidase 1) was also reported to mediate the Ras-dependent up-regulation of VEGF expression and, angiogenesis via the Ras/ERK-dependent Sp1 phosphorylation and activation in CaCO-2 colon cancer cells [80,81]. In human umbilical vein endothelial cell (HUVECs), Angiopoietin -1 (Ang1) induced transient ROS through the activation of endothelial specific tyrosine kinase receptor, Tie-2, and p44/42, MAPK leading to vascular remodeling [82]. 
Moreover, copper was reported to increase the ROS-mediated expression of VEGF, HiF- $1 \alpha$, and G-protein estrogen receptor (GPER) in HepG2 hepatocellular carcinoma cells and SkBr3 breast cancer cells via activation of the EGFR/ERK/c-Fos pathway [83,84]. Similarly, the cadmium activated ERK/Akt pathway induced ROS expression and HiF-1; its downstream pro-angiogenic molecule in BEAS-2B bronchial epithelial cells [85]. In addition, several other extracellular remodeling proteins and transcription factors (p53, HiF-1 $\alpha$, VEGF, and MMPs) have been documented to be regulated by ROS [86-91]. Also, numerous studies in cancer cell lines (MCF-7, HepG2, H-1299, PC-3) showed that ROS acted through the PI3K/Akt signaling cascade, thereby enhancing HiF-1 $\alpha$ expression and angiogenesis [92-94]. In view of literature supporting the angiogenic potential of ROS, therapeutic targets with antioxidant potential and targeting subsequent signaling cascades will be of clinical significance in the management and treatment of patients through down-regulation of neovascularization. Different strategies to restore redox imbalance is another avenue to improve outcome of diseases. As the interventional trials with small anti-oxidants have not been effective, further research to explore disease-specific ROS may be of clinical relevance for futuristic drug development.

\section{Role of ROS in Cancer Cell Killing}

\subsection{Cellular Apoptosis and ROS}

Almost all forms of DNA damage, like base modifications, strand breakage, DNA cross-linking, and proteins are induced by ROS, which are associated with cancer initiation and development [95]. However, a paradox in biological systems is that ROS can induce apoptotic cell death, which is an important approach in cancer therapeutics [96-98]. ROS disrupts the mitochondrial membrane and opens the mitochondrial permeability transition pore (PTP), and thus interferes with mitochondrial electron transfer chain and induces the release of Cytochrome-c. In the cytosol, together with Apaf-1 (apoptotic peptidase activating factor 1) and procaspase-9, Cytochrome-c forms 'apoptosomes' leading to the activation of caspase-9, which then activates effector caspases, e.g. caspase-3, that results in the cleavage of cellular proteins and apoptotic cell death (Figure 5) [99-102]. Indeed, hydrogen peroxide $\left(\mathrm{H}_{2} \mathrm{O}_{2}\right)$ is one of the most important among the ROS group which is a direct and potent inducer of apoptosis [103].

Numerous studies [104-108] have illustrated that anticancer agents induce cancer cell apoptosis and autophagy via ROS generation as detailed in Table 2. For example, natural polyphenol resveratrol was found to induce mitochondrial accumulation of $\mathrm{H}_{2} \mathrm{O}_{2}$ by regulating antioxidant enzymes, which in turn, induced apoptosis in PC-3 (prostate cancer), HepG2 (hepatic cancer), and MCF-7 (breast cancer) cells [109]. Some evidence have also shown that the black cumin component, thymoquinone, also act as a pro-oxidant and induces apoptosis by generating ROS through different molecular pathways, like activating Akt and causing conformational changes in BCL-2 associated X, apoptosis regulator (Bax) protein, which leads to the loss of mitochondrial membrane potential and release of cytochrome-c and subsequent activation of the caspase-dependent apoptotic pathway [110-114]. Several studies have also discovered that ginsenosides exert their anticancer activities by generating ROS via a signaling cascade, where ROS was found to be responsible for inducing apoptosis [115]. 


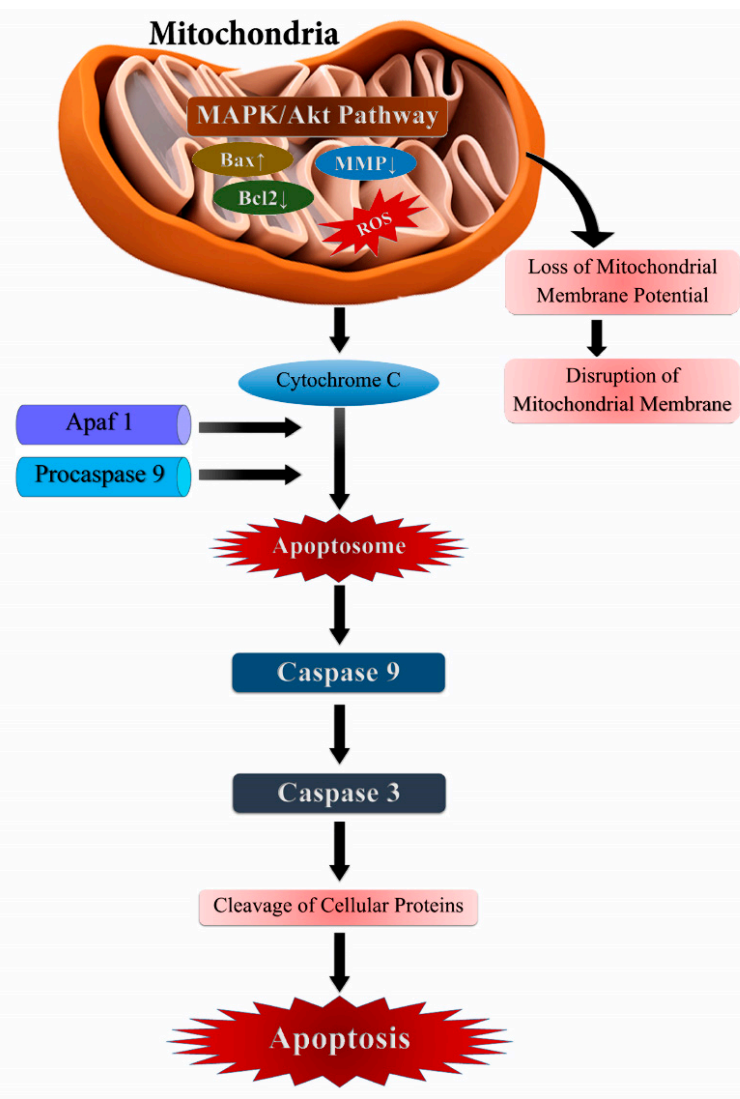

Figure 5. Exogenously or endogenously produced reactive oxygen species (ROS) activates extrinsic and intrinsic apoptosis pathways. ROS modulated cell-signaling activation of MAPK (Mitogen-activated protein kinases), Bcl_2 (BCL2 Apoptosis Regulator), and Bax (BCL2 Associated X, Apoptosis Regulator) which activates the downstream caspase cascade, leading to apoptotic cell death.

Table 2. Role of ROS in cancer cell death.

\begin{tabular}{|c|c|c|c|}
\hline Effect & Mechanism & Cell Line & References \\
\hline \multirow[t]{4}{*}{ Apoptosis } & $\begin{array}{l}\text { Increase in cell oxidation by c-Met-Nrf2-HO-1 pathway and } \\
\text { promotes apoptotic cell death }\end{array}$ & 786-O and $\mathrm{ACHN}$ & [116] \\
\hline & $\begin{array}{l}\text { Apoptosis enhanced by ROS by affecting MAPK \& AKT } \\
\text { signaling and DNA damage mediated p } 53 \text { phosphorylation }\end{array}$ & HePG-2 Cells & [117] \\
\hline & $\downarrow$ ROS by expression of GPx3 and leads to G2/M arrest & $\begin{array}{l}\text { H157, H460, A549, H1299, } \\
\text { H1650, and H1975 lung } \\
\text { cancer cells }\end{array}$ & [118] \\
\hline & $\begin{array}{l}\uparrow \text { ROS by knockdown of nicotinamide nucleotide } \\
\text { transhydrogenase and significant cell apoptosis under } \\
\text { oxidative Stress }\end{array}$ & $\begin{array}{l}\text { GES-1, SGC7901, SNU216, } \\
\text { MKN45, MKN74, BGC823, } \\
\text { HGC27 and MGC803 }\end{array}$ & [119] \\
\hline \multirow[t]{4}{*}{$\begin{array}{l}\text { Short } \\
\text { mRNA }\end{array}$} & $\begin{array}{l}\text { Salviamiltiorrhiza treatment induces apoptosis through } \\
\text { regulation of miR-216b and ROS/ER stress pathways }\end{array}$ & U266 and U937 Cells & [120] \\
\hline & $\begin{array}{l}\text { miR-21 silencing effect the ROS-induced activation, invasion, } \\
\text { migration, and glycolysis of Pancreatic stellate cells (PSCs) }\end{array}$ & Human PSCs, Panc-1 & [121] \\
\hline & $\begin{array}{l}\text { Down-regulation of NOX2 using siRNA technology in } \\
\text { decreased cell viability and ROS content }\end{array}$ & SNU719 cells & [122] \\
\hline & $\begin{array}{l}\text { Melanoma differentiation-associated gene-7/interleukin-24 } \\
\text { ( } m \text { da-7/IL-24) regulates miRNA biogenesis through alteration } \\
\text { of ROS-dependent MITF-DICER pathway }\end{array}$ & Animal cancer model & [123] \\
\hline \multirow[t]{3}{*}{ Autophagy } & $\begin{array}{l}\text { Silencing of YAP enhanced autophagic flux by increasing } \\
\text { RAC1-driven ROS, through inactivation of mTOR }\end{array}$ & BEL/FU, BEL-7402 & [124] \\
\hline & $\begin{array}{l}\text { Zinc Oxide Nanoparticle (ZON) evoked autophagy by } \\
\text { accelerating the intracellular dissolution of ZONs and ROS } \\
\text { generation. }\end{array}$ & MCF-7/ADR & [125] \\
\hline & $\begin{array}{l}\text { Cell killing was due to the summative effect of } \\
\text { caspase-dependent intrinsic apoptosis and } \\
\text { caspase-independent autophagy by activation of MAPK } \\
\text { family members (ERK1/2 and JNK) with generation of ROS }\end{array}$ & SNU-719 & [126] \\
\hline
\end{tabular}




\subsection{Autophagy and ROS}

The process of autophagy, involving degradation of organelles and proteins, plays a crucial role in cellular processes which is associated with elevated ROS levels. Numerous studies have documented the role of ROS regulation in the mediation of autophagy [127-129]. The diverse effects of autophagy range from prevention of infection to pathogen elimination to cell death of dysfunctional cellular organelles. These consequences indicate the potential of ROS to act as a signaling target in survival related to autophagy [130-132]. Recently, research has transitioned into looking for the potential applicability of ROS-derived autophagy in the treatment of malignancies [133-135]. The intracellular ROS levels have also been reported to directly corroborate with the regulation of autophagy induction in malignant tumors $[136,137]$. Autophagy related 4A cysteine peptidase (ATG4) enzyme oxidation, a prerequisite for de-lipidation of the ATG8 protein, induced by $\mathrm{H} 2 \mathrm{O} 2$ leads to the induction of autophagy. This $\mathrm{H} 2 \mathrm{O} 2$-induced oxidation in turn inactivates ATG4 which subsequently results in an elevated LC3-associated autophagosomes production [136]. On the other hand, the AMP-activated protein kinase (AMPK) pathway also plays a major role in the ROS related autophagy regulation. This activation of AMPK inhibits mTORC1 resulting in autophagy induction. Additionally, oxidative stress also regulates AMPK pathway activation via phosphorylation of AMPKK (AMPK kinase) which increases $\mathrm{H} 2 \mathrm{O} 2$ production, thereby resulting in apoptosis induction [136]. In addition, various transcription factors e.g., NF- $\mathrm{kB}$ can also modulate the expression of autophagy-associated genes (ATG6/BECLIN1 or p62/SQSTM1) which directs ROS induced autophagy in cancer $[138,139]$. In an initial study by Kim and colleagues, SOD overproduction was documented to inhibit selenite induced cytotoxicity (autophagy) in human glioma cells [140]. Additionally, small miRNA was reported to knockout ATG6/7 (Autophagy related gene 6 and 7), which in turn reduced selenite induced cytotoxicity $[132,141,142]$. Based on these findings, it has been postulated that elevated ROS levels and its modulation induces autophagy in malignant cells.

\subsection{Anticancer Therapy and ROS}

ROS concentration in tumor cells is very critical in anticancer therapy. High ROS levels are documented to induce cytotoxicity along with reversal of chemotherapeutic resistance in tumorigenic cells. Several investigations are suggestive of the fact that elevated ROS levels is the underlying core mechanism of action and efficacy of conventional cancer therapies which is directly associated with cancer cell death [143-146]. The mechanism of elevated ROS levels to target malignant cells is either via augmenting ROS generation through exogenous agents or inhibitors of the antioxidant system.

\subsection{Inhibition of Antioxidant System in Cancer Cells}

The disruption or inhibition of cellular antioxidant enzymes augment ROS production which trigger apoptosis in malignant cells. SOD, Glutathione (GSH) system, and Thioredoxin 1 (Trx) are the major targets of ROS enhancing antitumor agents $[142,147,148]$. In a normal healthy cell, ROS levels are low which signify their lower dependence on antioxidant enzymes. Numerous studies have reported the findings that inhibition of cellular antioxidant system lead to the induction of ROS-mediated cytotoxicity (autophagy) in different types of cancers [147,149-152]. Further, elevated cellular antioxidant levels are also reported to be directly involved in developing chemoresistance in malignant cells. To overcome chemotherapy resistance, many chemotherapeutic compounds and antitumor agents have been developed which specifically target intracellular GSH levels. For example, administration of PEITC (phenethyl isothiocyanate) in combination with GSH alleviates the GSH pool, subsequently stemming oxidative stress leading to cytotoxicity in malignant cells. This was further reported to block GPX in HRAS-transformed ovarian carcinoma cells, thereby inducing cell death $[149,153,154]$. In another study on similar lines, $\beta$-PIETC was documented to block GPX thereby decreasing GSH levels which induced high ROS expression in tumor cells [155-157]. Hence, targeting and reducing GST and GSH levels is illustrated to restore the cytotoxic ability of various 
arsenic derivatives, alkylating agents, and platinum derived agents. Buthioninesulfoximine (BSO) has been identified to halt GSH production and is being increasingly studied owing to its high sensitivity [158-160]. ATO (Arsenic trioxide) and BSO administration in acute promyelocytic leukemia (APL) was reported to synergistically reduce GSH levels thereby inducing apoptosis [161-164]. Similarly, copper $\mathrm{N}$-glycinate (CuNG), a copper derivative, has been illustrated to target GSH in Ehrlich ascites carcinoma and stimulate ROS production [164-166].

In addition to GSH, SOD1 can also be targeted specifically to induce apoptosis in different types of cancers. This SOD inhibition has presented as a promising approach for targeting tumor cells. In an in vitro study carried out on lung adenocarcinoma, inhibition of SOD1 alleviated the growth of KRAS-mutant tumor cells $[147,167]$. Similarly, in another study, methoxyestradiol (2-ME), was illustrated to block SOD, which lead to the induction of cell death in leukemia cells. NRF2, is also a key regulator of cellular antioxidants and KRAS and MYC oncogenes have been reported to mediate NRF2 transcription. Hence, NRF2 can be therapeutically targeted to stimulate ROS-induced apoptosis in tumor cells $[168,169]$.

Additionally, Trx and TrxR is also an appropriate target for the development of novel antitumor treatments. This is attributed to augmented Trx and TrxR levels reported to positively correlate with tumor progression, chemo resistance, and poor survival [170-172] Presently, several compounds specially targeting Trx are being explored on the scientific front in pre-clinical and clinical models. For instance, a Trx-blocker, motexafin gadolinium, in phase III clinical trials has shown to specifically target malignant cells $[173,174]$.

\subsection{Production of ROS Directly in Cancer Cells}

Inhibition of antioxidant enzymes is another therapeutic approach in the induction of ROS production in tumor cells $[143,175]$. Numerous approaches have been developed to administer ROS and ROS producing agents in vitro in cell cultures, which would enhance ROS levels and ultimately cause cellular damage $[176,177]$. Some of these compounds have been approved as anticancer drugs and many are still being developed. These drugs/agents are either used alone or in combination with chemotherapy and/or radiotherapy. Of these, some chemotherapeutic agents like antifolates, alkaloids, and taxanes, disrupt the mitochondrial electron transport chain (ETC), thereby resulting in high O2levels and the induction of mitochondria-mediated cell cytotoxicity [178-180]. Other chemotherapeutic agents like doxorubicin and cisplatin also lead to increased ROS production, levels of which are cytotoxic to tumor cells.

Procarbazine was the first ROS inducing drug used in anticancer therapy [181]. Procarbazines lead to the production of azo-derivatives, which in turn lead to ROS generation and oxidative DNA damage. In 1963, the first clinical trial of Procarbazine was conducted following which it was approved as a cytotoxic agent for treatment of brain tumors and Hodgkin's lymphoma [182-184]. In last span of 15 years, numerous conventional antitumor agents inducing ROS as a cancer therapeutic modality has been extensively investigated for their safety and efficacy. For instance, doxorubicin and anthracyclines induce ROS production and are widely used in the treatment of acute lymphocytic leukemia (ALL), bladder cancer, lymphoma, Kaposi's sarcoma (KS), breast cancer, and other malignancies [185-188]. In addition, biological molecules can also stimulate ROS generation leading to apoptotic cell death. ROS-dependent arsenic drugs are reported to be used in APL treatment $[178,189]$. Also, Imexon has shown to elevate oxidative stress and stimulate apoptosis in cancer cells. In preclinical investigations and phase I/II clinical trials, the safety and anticancer effect of Imexon has been very well studied in leukemia [190].

Several anticancer drugs have also been reported to disrupt the ETC, resulting in elevated ROS production [179]. Further, these ROS-generating agents directly target the complex I/II of ETC $[175,180]$. For example, ATO has been successfully used for the treatment of APL patients, wherein ATO leads to the generation of ROS via NADPH oxidase, which in turn induces apoptotic cell death $[178,189]$. 
Some studies have also indicated that administration of therapeutic agents increasing ROS production along with conventional chemotherapies, have shown increased efficacy in targeting tumor cells $[175,191,192]$. The synergizing effect of emodin and ROS-inducing therapeutic agents have been documented to induce cell apoptosis in different types of cancers [192-194]. Further, the safety was also monitored and was shown to cause negligible damage to healthy cells.

\section{6. miRNAs and ROS}

As both reactive oxygen species and microRNAs (miRNAs) are dysregulated in cancers, it is imperative to understand their association, and how they maintain homeostasis and avert tumorigenic conversion from a healthy cell. In view of reported scientific literature, accumulative evidence is suggestive of the crosstalk between ROS signaling and miRNAs expression. miRNAs are a class of small endogenous non-protein coding RNAs that have the size of approximately $\sim 22 \mathrm{nts}$; they are capable of altering the expression of target genes at the post-transcriptional level, mainly by binding at the 3'UTR region of their mRNA [195]. In this section, we are going to discuss the latest findings on ROS-mediated regulation of miRNAs, ROS pathways regulated by miRNAs in cancer, and the ROS-miRNAs axis as a potential target for cancer as illustrated in Figure 6.

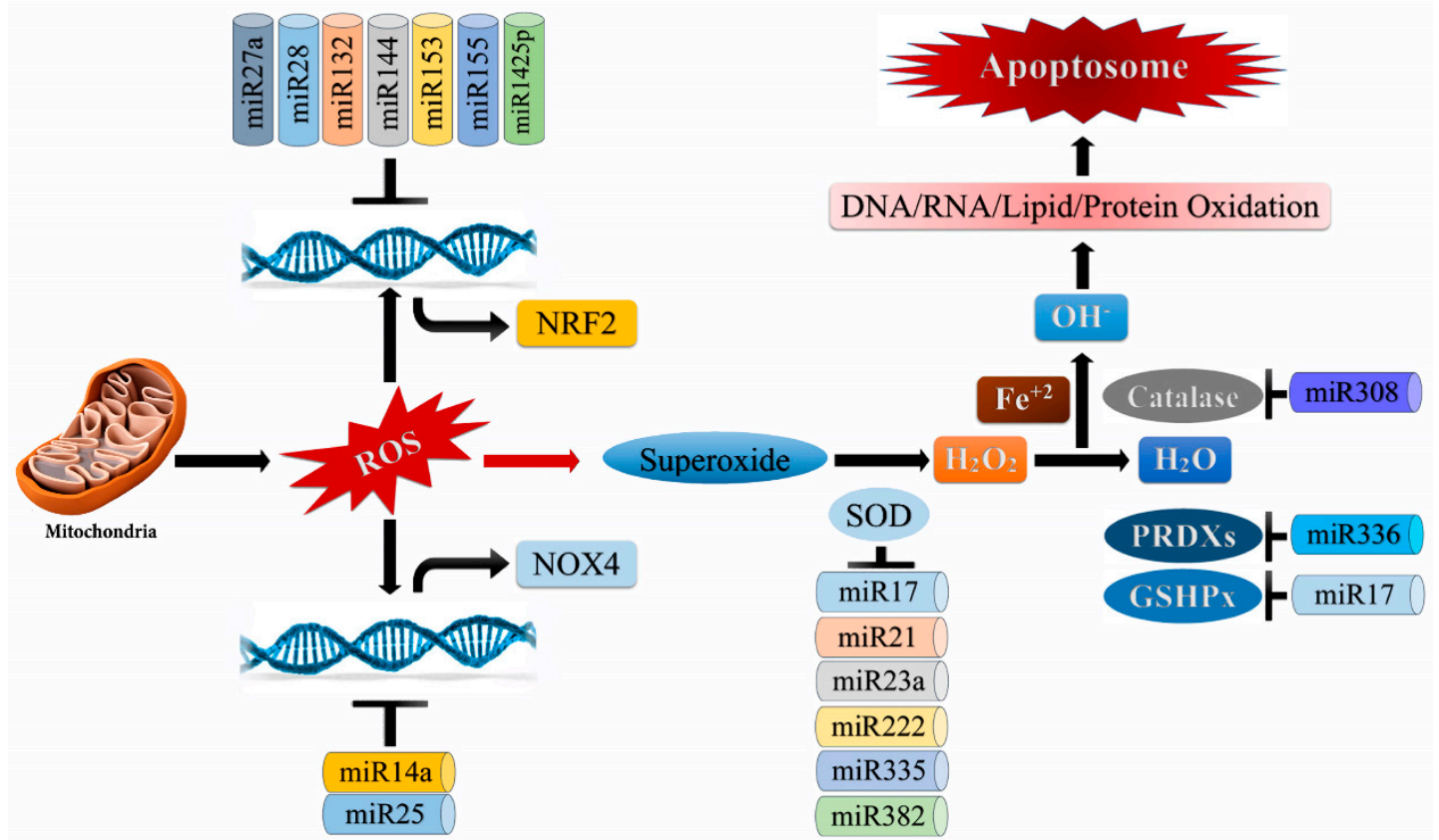

Figure 6. Regulation of microRNA biogenesis through reactive oxygen species (ROS): Complex I/III in mitochondria leads to elevated superoxide anion $\left(\mathrm{O}_{2}{ }^{-}\right)$production. Superoxide dismutase (SOD) converts $\mathrm{O}_{2}^{-}$to $\mathrm{H}_{2} \mathrm{O}_{2}$ (hydrogen peroxide), which is acted upon by glutathione peroxidase (GSHPx)/ catalase (CATs) and converted to $\mathrm{H}_{2} \mathrm{O}$ (water). $\mathrm{H}_{2} \mathrm{O}_{2}$ leads to Hydroxyl radicals $(\mathrm{OH})$ production leading to DNA/RNA/lipid/protein degradation.

In an interesting study by Yang et al., 2019, [196], the group reported that the deprivation of glutamine in pancreatic ductal adenocarcinoma (PDAC) cells can lead to significant up-regulation ( 3-fold) of miR-135a and miR-135b expression as compared to PDAC cells having glutamine [196]. Further, it was shown that when PDAC were treated with an antioxidant $N$-acetyl-L-Cysteine glutamine molecule, the levels of miR-135a and miR-135b decreased, which suggested that the induction of the miR-135 family is ROS-dependent. Glutamine is known to regulate the ROS level in the cells [197]. Mechanistically, it was demonstrated that low levels of glutamine in cells induced ROS species activation, which in turn activates mutant p53 and increases the expression of miR-135 by binding to its promoter [196]. 
Another group have shown that when hepatocellular carcinoma cells (HepG2) were exposed to $\mathrm{H}_{2} \mathrm{O}_{2}$ there was a significant decrease ( 1.5 fold) in the expression of miR-145 and miR-128 levels in the cells [198]. Further, the authors have demonstrated that the insulin-induced ROS is responsible for the decrease in miR-145 and miR-128 expression in cells, and the overexpression of either miR-145 or miR-128 eliminates insulin-induced ROS and pyruvate kinase M2 expression. It was also shown that when vascular cells were exposed to a high concentration of $\mathrm{H}_{2} \mathrm{O}_{2}$, the expression of miR-200c up-regulated, which further leads to cellular apoptosis and senescence through binding of the ZEB transcription factor 1 (ZEB1) [199]. Normally miR-200c acts as a tumor suppressor in the bladder, gastric, and ovarian cancers. Similarly, another group reported a group of four miRNA signatures namely, miRNAs let-7s, miR-34s, miR-200s, and miR-182, which were significantly increased in high-grade serous ovarian carcinoma cells post- $\mathrm{H}_{2} \mathrm{O}_{2}$ exposure [200]. They further demonstrated that ROS up-regulates $\beta$-catenin, which in turn regulate the expression of miR-182 in cells. He et al., 2012 have demonstrated that via epigenetic mechanisms, ROS decreases miR-199a and miR-125b expression in ovarian cancer cells, through the promoter methylation of miR-199a and miR-125b [201]. It was also documented that Chidamide, a HDAC inhibitor (HDACi), increased ROS production in cells and up-regulated miR-129-3p expression in H1355 and A549 lung adenocarcinoma cells [202]. In cells, Chidamide suppressed telomerase activity through ROS accumulation and cell cycle arrest.

In addition to acting as an essential target of ROS-mediated stress molecules, miRNAs are also found to control genes that are either ROS activators or scavengers. For example, miR-9 suppressed the glutamic-oxaloacetic transaminase (GOT1) gene by directly binding to its 3'-UTR in melanoma cells, which subsequently abridged erastin- and RSL3-induced ferroptosis. Ferroptosis is a form of cell death process driven by lipid-based ROS accumulation [203]. Another study showed that miR-34a directly targets the NOX2 gene and induces apoptosis in glioma cells through NOX2-derived ROS generation [204]. The NOX2 subunit is the catalytic core of the NADPH oxidase complex, which is considered as the major source of ROS production in epithelial cells and increases cancer risk [205,206]. Similarly, miR-23b was reported to down-regulate proline oxidase expression by directly targeting its $3^{\prime}$ UTR and thereby promoting renal cancer [207]. The proline oxidase gene is a mitochondrial tumor suppressor gene that is known to induce apoptosis through ROS production and also reduces HIF [208]. He et al., 2018 have demonstrated that the miR-422 a-pyruvate dehydrogenase kinase 2 axis influence de novo lipogenesis in gastric cancer cells, that subsequently increases ROS production and rapid hypo-phosphorylation of retinoblastoma protein and finally cell cycle arrest at the G1 phase of the cell cycle [209]. Furthermore, another group have shown that miR-148b suppressed cell proliferation and regulated the oxidative stress response in human endometrial cancer RL95-2 cells by decreasing the expression of HIF-1 $\alpha$ and nuclear factor erythroid 2-related factor by down regulating the endoplasmic reticulum MMP1 gene [210].

From the above-mentioned studies, it is very clear that both ROS and miRNAs are interlinked to each other and play an important role in the pathogenesis of cancer. Hence, the future targeting of ROS with miRNAs inhibitors may represent a novel therapeutic approach for the treatment of cancer.

\section{ROS: A Double-Edged Sword}

In a normal cell, redox homeostasis is sustained amidst ROS production and exclusion due to the conserved antioxidant mechanism via enzymes (glutathione peroxidase, superoxide dismutase, and catalase) and transcription factor Nrf2 [211]. Excessive ROS generation leads to a defective antioxidant defense mechanism, incompetent to scavenge excess, thereby leading to impaired balance between antioxidants and pro-oxidants. Recent literature has emphasized the dichotomous nature of ROS in malignant cells, depending on the stage of cancer progression i.e., early stage/late stage, on the basis of which differential effects of ROS are reported in tumor cells. In a tumorous cell, elevated ROS production initiates an adaptation reaction, which subsequently maintains the redox balance. At the precancerous/early stage of tumor progression, moderate ROS levels induce tumorigenesis, tumor promulgation, metastasis, and survival [211]. With tumor progression, elevated ROS levels 
beyond the toxic threshold lead to cell death, apoptosis [212,213], and senescence [212]. Through the inclusion of dietary antioxidants i.e., phytochemicals, the level of cellular antioxidants can be regulated, which can in turn regulate the growth inhibition and cell death in malignant cells. In MCF-7 breast cancer cells, tamoxifen-induced cytotoxicity was reported to be regulated via the intracellular concentration of vitamin $C$, which inhibited lipid peroxidation leading to decreased ROS levels [214]. In addition, in MDA-MB-435, SKBR-3, and MDA-MB-231 cells, resveratrol reduced ROS accumulation which was shown to decrease paclitaxel-induced cell death $[215,216]$. Vitamin E was also reported to decrease ROS production in a dose-dependent manner in a MCF-7 orthotropic breast tumor model. The results from the study showed decreased ROS levels post- 12 days treatment followed by tumor growth in breast cancer cells and p53 expression [217]. On the other hand, phytochemicals like vitamin C, resveratrol, apigenin, luteolin, and epigallocatechin-3-gallate etc. have been reported to have pro-oxidant effects leading to elevated ROS levels and cell death. In an in vitro study, elevated vitamin $\mathrm{C}$ doses have been reported to induce pro-oxidant activity via high $\mathrm{H}_{2} \mathrm{O}_{2}$ generation [218]. In MCF-7 breast cancer cells and HT29 colon cancer cells, vitamin C-induced oxidative stress can lead to NAD depletion and inhibition of energy metabolism causing cellular apoptosis [219]. Resveratrol was also seen to have pro-oxidant activity resulting in elevated formation of hydroxyl radicals in the presence of copper ions $[220,221]$. These phytochemicals are being increasingly explored for the development of ROS-targeted killing of tumor cells as anticancer therapeutic agents.

\section{Conclusions and Future Perspectives}

For the healthy functioning of normal cells, a delicate balance in ROS redox processes, which maintains physiological homeostasis, is critical. This is elicited in numerous in vitro and in vivo studies emphasizing the significant role of ROS homeostasis in cellular signaling. ROS also plays a pivotal role in cellular processes, with low levels playing a substantial role in the regulation of signaling cascades while higher concentrations of ROS initiates apoptosis/cell damage. The decrease in effective neutralization of excessive ROS can result in different serious diseases, such as cancer. The aberrant production of ROS leads to cancer growth and progression via different signaling pathways (PI3/Akt/mTOR, PTEN, MAPK, VEGF/VEGFR, and MMPs). However, the substantial increase in ROS levels has been shown to intervene in processes important for cancer progression, initiate apoptosis, and contribute to cell death induced by traditional therapeutic modalities, including chemotherapy. A number of chemotherapeutic drugs have been reported to induce apoptosis through ROS. As ROS have diverse molecular targets in cells, their activities are also regulated by a wide range of signaling pathways. ROS is also known to cause drug resistance to chemotherapeutic treatments. It acts through the activation of NF- $\mathrm{kB}$, which triggers the secretion of pro-inflammatory cytokines. Hence, the dual role of ROS should be exploited as a therapeutic target to inhibit tumor growth via impeding inflammation, angiogenesis, and metastasis. To develop an effective anti-tumor treatment modality, the scientific groups need to completely comprehend ROS and its redox state in malignancies, which is still enigmatic despite extensive research.

Funding: This research received no external funding.

Conflicts of Interest: The authors declare no conflict of interests.

\section{References}

1. The Lancet. GLOBOCAN 2018: Counting the toll of cancer. Lancet 2018, 392. [CrossRef]

2. Saikolappan, S.; Kumar, B.; Shishodia, G.; Koul, S.; Koul, H.K. Reactive oxygen species and cancer: A complex interaction. Cancer Lett. 2019, 452, 132-143. [CrossRef] [PubMed]

3. Nourazarian, A.R.; Kangari, P.; Salmaninejad, A. Roles of oxidative stress in the development and progression of breast cancer. Asian Pac. J. Cancer Prev. 2014, 15, 4745-4751. [CrossRef] [PubMed] 
4. Zhang, J.; Ahn, K.S.; Kim, C.; Shanmugam, M.K.; Siveen, K.S.; Arfuso, F.; Samym, R.P.; Deivasigamanim, A.; Lim, L.H.K.; Wang, L.; et al. Nimbolide-induced oxidative stress abrogates STAT3 signaling cascade and inhibits tumor growth in transgenic adenocarcinoma of mouse prostate model. Antioxid. Redox Signal. 2016, 24, 575-589. [CrossRef] [PubMed]

5. Morgan, M.J.; Liu, Z.-g. Crosstalk of reactive oxygen species and NF-kB signaling. Cell Res. 2011, 21, $103-115$. [CrossRef]

6. Puar, Y.; Shanmugam, M.; Fan, L.; Arfuso, F.; Sethi, G.; Tergaonkar, V. Evidence for the involvement of the master transcription factor NF- $\mathrm{KB}$ in cancer initiation and progression. Biomedicines 2018, 6, 82. [CrossRef]

7. Rodrigues, C.; Pimpão, C.; Mósca, A.F.; Coxixo, A.S.; Lopes, D.; da Silva, I.V.; Pedersen, P.A.; Antunes, F.; Soveral, G. Human Aquaporin-5 Facilitates Hydrogen Peroxide Permeation Affecting Adaption to Oxidative Stress and Cancer Cell Migration. Cancers 2019, 11, 932. [CrossRef]

8. $\quad$ Liang, W.; Zhang, Y.; Song, L.; Li, Z. 2, 3'4 4, 4' , 5-Pentachlorobiphenyl induces hepatocellular carcinoma cell proliferation through pyruvate kinase M2-dependent glycolysis. Toxicol. Lett. 2019, 313, 108-119. [CrossRef]

9. Sarkar, R.; Kishida, S.; Kishida, M.; Nakamura, N.; Kibe, T.; Karmalar, D.; Chaudhuri, C.R.; Barui, A. Effect of cigarette smoke extract on mitochondrial heme-metabolism: An in vitro model of oral cancer progression. Toxicol. In Vitro 2019, 60, 336-346. [CrossRef]

10. Bousquet, P.A.; Meltzer, S.; Sønstevold, L.; Esbensen, Y.; Dueland, S.; Flatmark, K.; Sitter, B.; Bathen, T.F.; Seierstad, T.; Redalen, K.R.; et al. Markers of mitochondrial metabolism in tumor hypoxia, systemic inflammation, and adverse outcome of rectal cancer. Transl. Oncol. 2019, 12, 76-83. [CrossRef]

11. Echizen, K.; Oshima, H.; Nakayama, M.; Oshima, M. The inflammatory microenvironment that promotes gastrointestinal cancer development and invasion. Adv. Biol. Regul. 2018, 68, 39-45. [CrossRef] [PubMed]

12. Zanotto-Filho, A.; Rajamanickam, S.; Loranc, E.; Masamsetti, V.P.; Gorthi, A.; Romero, J.C.; Tonapi, S.; Gonçalves, R.M.; Reddick, R.L.; Benavides, R.; et al. Sorafenib improves alkylating therapy by blocking induced inflammation, invasion and angiogenesis in breast cancer cells. Cancer Lett. 2018, 425, 101-115. [CrossRef] [PubMed]

13. Lee, S.Y.; Ju, M.K.; Jeon, H.M.; Lee, Y.J.; Kim, C.H.; Park, H.G.; Han, S.I.; Kang, H.S. Reactive oxygen species induce epithelial-mesenchymal transition, glycolytic switch, and mitochondrial repression through the Dlx-2/Snail signaling pathways in MCF-7 cells. Mol. Med. Rep. 2019, 20, 2339-2346. [CrossRef] [PubMed]

14. Wang, C.; Shao, L.; Pan, C.; Ye, J.; Ding, Z.; Wu, J.; Du, Q.; Ren, Y.; Zhu, C. Elevated level of mitochondrial reactive oxygen species via fatty acid $\beta$-oxidation in cancer stem cells promotes cancer metastasis by inducing epithelial-mesenchymal transition. Stem Cell Res. Ther. 2019, 10. [CrossRef] [PubMed]

15. Sun, H.F.; Yang, X.L.; Zhao, Y.; Tian, Q.; Chen, M.T.; Zhao, Y.Y.; Jin, W. Loss of TMEM126A promotes extracellular matrix remodeling, epithelial-to-mesenchymal transition, and breast cancer metastasis by regulating mitochondrial retrograde signaling. Cancer Lett. 2019, 440, 189-201. [CrossRef]

16. Deng, X.; Feng, N.; Zheng, M.; Ye, X.; Lin, H.; Yu, X.; Gan, Z.; Fang, Z.; Zhang, H.; Gao, M.; et al. PM PM $_{2.5}$ exposure-induced autophagy is mediated by lncRNA loc146880 which also promotes the migration and invasion of lung cancer cells. Biochimica Biophysica Acta Gen. Subj. 2017, 1861, 112-125. [CrossRef]

17. Wang, N.; Zhan, T.; Ke, T.; Huang, X.; Ke, D.; Wang, Q.; Li, H. Increased expression of RRM2 by human papillomavirus E7 oncoprotein promotes angiogenesis in cervical cancer. Br. J. Cancer 2014, 110, 1034-1044. [CrossRef]

18. Kansestani, A.N.; Mansouri, K.; Hemmati, S.; Zare, M.E.; Moatafaei, A. High Glucose-reduced Apoptosis in Human Breast Cancer Cells Is Mediated by Activation of NF-kB. Iran. J. Allergy Asthma Immunol. 2019, 18, 153-162. [CrossRef]

19. Zhu, D.; Shen, Z.; Liu, J.; Chen, J.; Liu, Y.; Hu, C.; Li, Z.; Li, Y. The ROS-mediated activation of STAT-3/VEGF signaling is involved in the 27-hydroxycholesterol-induced angiogenesis in human breast cancer cells. Toxicol. Lett. 2016, 264, 79-86. [CrossRef]

20. Gerschmann, R.; Gilbert, D.; Nye, S.W.; Dwyer, P.; Fenn, W.O. Oxygen poisoning and X-irradiation: A mechanism in common.1954. Nutrition 2001, 17, 162.

21. Valko, M.; Leibfritz, D.; Moncol, J.; Cronin, M.T.; Mazur, M.; Telser, J. Free radicals and antioxidants in normal physiological functions and human disease. Int. J. Biochem. Cell Biol. 2007, 39, 44-84. [CrossRef] [PubMed]

22. Harman, D. Aging: A theory based on free radical and radiation chemistry. J. Gerontol. 1956, 11, $298-300$. [CrossRef] [PubMed] 
23. McCord, J.M.; Fridovich, I. Superoxide dismutase an enzymic function for erythrocuprein (hemocuprein). J. Biol. Chem. 1969, 244, 6049-6055. [PubMed]

24. Lenaz, G. Mitochondria and reactive oxygen species. Which role in physiology and pathology? Adv. Exp. Med. Biol. 2012, 942, 93-136. [PubMed]

25. Franco, R.; Schoneveld, O.; Georgakilas, A.G.; Panayiotidis, M.I. Oxidative stress, DNA methylation and carcinogenesis. Cancer Lett. 2008, 266, 6-11. [CrossRef]

26. Dalle-Donne, I.; Rossi, R.; Colombo, R.; Giustarini, D.; Milzani, A. Biomarkers of oxidative damage in human disease. Clin. Chem. 2006, 52, 601-623. [CrossRef]

27. Reuter, S.; Gupta, S.C.; Chaturvedi, M.M.; Aggarwal, B.B. Oxidative stress, inflammation, and cancer: How are they linked? Free Radic. Biol. Med. 2010, 49, 1603-1616. [CrossRef]

28. Korniluk, A.; Koper, O.; Kemona, H.; Dymicka-Piekarska, V. From inflammation to cancer. Ir. J. Med. Sci. 2017, 186, 57-62. [CrossRef]

29. Balkwill, F.; Mantovani, A. Inflammation and cancer: Back to Virchow? Lancet 2001, 357, 539-545. [CrossRef]

30. Grivennikov, S.I.; Greten, F.R.; Karin, M. Immunity, inflammation, and cancer. Cell 2010, 140, 883-899. [CrossRef]

31. Gonda, T.A.; Tu, S.; Wang, T.C. Chronic inflammation, the tumor microenvironment and carcinogenesis. Cell Cycle 2009, 8, 2005-2013. [CrossRef] [PubMed]

32. Landskron, G.; De la Fuente, M.; Thuwajit, P.; Thuwajit, C.; Hermoso, M.A. Chronic inflammation and cytokines in the tumor microenvironment. J. Immunol. Res. 2014. [CrossRef] [PubMed]

33. Wu, Y.; Antony, S.; Meitzler, J.L.; Doroshow,J.H. Molecular mechanisms underlying chronic inflammation-associated cancers. Cancer Lett. 2014, 345, 164-173. [CrossRef] [PubMed]

34. Kashyap, D.; Tuli, H.S.; Sak, K.; Garg, V.K.; Goel, N.; Punia, S.; Chaudhary, A. Role of Reactive Oxygen Species in Cancer Progression. Curr. Pharmacol. Rep. 2019, 5, doi. [CrossRef]

35. Forrester, S.J.; Kikuchi, D.S.; Hernandes, M.S.; Xu, Q.; Griendling, K.K. Reactive oxygen species in metabolic and inflammatory signaling. Circ. Res. 2018, 122, 877-902. [CrossRef]

36. Azad, N.; Rojanasakul, Y.; Vallyathan, V. Inflammation and lung cancer: Roles of reactive oxygen/nitrogen species. J. Toxicol. Environ. Health B Crit. Rev. 2008, 11, 1-15. [CrossRef]

37. Liu, X.; Chen, Z. The pathophysiological role of mitochondrial oxidative stress in lung diseases. J. Transl. Med. 2017, 15. [CrossRef]

38. Li, F.; Sethi, G. Targeting transcription factor NF- $\kappa \mathrm{B}$ to overcome chemoresistance and radioresistance in cancer therapy. Biochimica Biophysica Acta 2010, 1805, 167-180. [CrossRef]

39. Zheng, H.C. The molecular mechanisms of chemoresistance in cancers. Oncotarget 2017, 8, 59950-59964. [CrossRef]

40. Chua, A.W.L.; Hay, H.S.; Rajendran, P.; Shanmugam, M.K.; Li, F.; Bist, P.; Koay, E.S.; Lim, L.H.; Kumar, A.P.; Sethi, G. Butein downregulates chemokine receptor CXCR4 expression and function through suppression of NF-kB activation in breast and pancreatic tumor cells. Biochem. Pharmacol. 2010, 80, 1553-1562. [CrossRef]

41. Nair, A.S.; Shishodia, S.; Ahn, K.S.; Kunnumakkara, A.B.; Sethi, G.; Aggarwal, B.B. Deguelin, an Akt inhibitor,

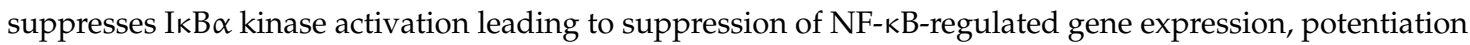
of apoptosis, and inhibition of cellular invasion. J. Immunol. 2006, 177, 5612-5622. [CrossRef]

42. Ahn, K.S.; Sethi, G.; Chaturvedi, M.M.; Aggarwal, B.B. Simvastatin, 3-hydroxy-3-methylglutaryl coenzyme A reductase inhibitor, suppresses osteoclastogenesis induced by receptor activator of nuclear factor- $\mathrm{KB}$ ligand through modulation of NF-kB pathway. Int. J. Cancer 2008, 123, 1733-1740. [CrossRef]

43. Manna, S.K.; Aggarwal, R.S.; Sethi, G.; Aggarwal, B.B.; Ramesh, G.T. Morin (3, 5, 7, 2' ' 4' - pentahydroxyflavone) abolishes nuclear factor- $\mathrm{kB}$ activation induced by various carcinogens and inflammatory stimuli, leading to suppression of nuclear factor-kB-regulated gene expression and up-regulation of apoptosis. Clin. Cancer Res. 2007, 13, 2290-2297. [CrossRef] [PubMed]

44. Hanahan, D.; Weinberg, R.A. Hallmarks of cancer: The next generation. Cell 2011, 144, 646-674. [CrossRef]

45. Seyfried, T.N.; Huysentruyt, L.C. On the origin of cancer metastasis. Crit. Rev. Onco. 2013, 18, 43-73. [CrossRef]

46. Brooks, S.A.; Lomax-Browne, H.J.; Carter, T.M.; Kinch, C.E.; Hall, D.M. Molecular interactions in cancer cell metastasis. Acta Histochemica 2010, 112, 3-25. [CrossRef]

47. Guerrini, L.; Garcia-Rico, E.; Alvarez-Puebla, R. The Role of Nanoscience in Cancer Diagnosis. In Handbook of Nanomaterials for Cancer Theranostics; Conde, J., Ed.; Elsevier: Amsterdam, The Netherlands, 2018; pp. 177-197. 
48. Chitty, J.L.; Filipe, E.C.; Lucas, M.C.; Herrmann, D.; Cox, T.R.; Timpson, P. Recent advances in understanding the complexities of metastasis. F1000Research 2018. [CrossRef]

49. Liao, Z.; Chua, D.; Tan, N.S. Reactive oxygen species: A volatile driver of field cancerization and metastasis. Mol. Cancer 2019, 18. [CrossRef]

50. Kamiya, T.; Goto, A.; Kurokawa, E.; Hara, H.; Adachi, T. Cross talk mechanism among EMT, ROS, and histone acetylation in phorbol ester-treated human breast cancer MCF-7 cells. Oxid. Med. Cell. Longev. 2016. [CrossRef]

51. Shin, D.H.; Dier, U.; Melendez, J.A.; Hempel, N. Regulation of MMP-1 expression in response to hypoxia is dependent on the intracellular redox status of metastatic bladder cancer cells. Biochim. Biophys. Acta 2015, 1852, 2593-2602. [CrossRef]

52. Zhang, B.; Liu, Z.; Hu, X. Inhibiting cancer metastasis via targeting NAPDH oxidase 4. Biochem. Pharmacol. 2013, 86, 253-266. [CrossRef] [PubMed]

53. Pelicano, H.; Lu, W.; Zhou, Y.; Zhang, W.; Chen, Z.; Hu, Y.; Huang, P. Mitochondrial dysfunction and reactive oxygen species imbalance promote breast cancer cell motility through a CXCL14-mediated mechanism. Cancer Res. 2009, 69, 2375-2383. [CrossRef] [PubMed]

54. Bagati, A.; Moparthy, S.; Fink, E.E.; Bianchi-Smiraglia, A.; Yun, D.H.; Kolesnikova, M.; Udartseva, O.O.; Wolff, D.W.; Roll, M.V.; Lipchick, B.C.; et al. KLF9-dependent ROS regulate melanoma progression in stage-specific manner. Oncogene 2019, 38, 3585-3597. [CrossRef] [PubMed]

55. Zucker, S.N.; Fink, E.E.; Bagati, A.; Mannava, S.; Bianchi-Smiraglia, A.; Bogner, P.N.; Wawrzyniak, J.A.; Foley, C.; Leonova, K.I.; Grimm, M.J.; et al. Nrf2 amplifies oxidative stress via induction of Klf9. Mol. Cell 2014, 53, 916-928. [CrossRef]

56. Jin, M.; Wang, J.; Ji, X.; Cao, H.; Zhu, J.; Chen, Y.; Yang, J.; Zhao, Z.; Ren, T.; Xing, J. MCUR1 facilitates epithelial-mesenchymal transition and metastasis via the mitochondrial calcium dependent ROS/Nrf2/Notch pathway in hepatocellular carcinoma. J. Exp. Clin. Cancer Res. 2019, 38. [CrossRef]

57. Aydin, E.; Johansson, J.; Nazir, F.H.; Hellstrand, K.; Martner, A. Role of NOX2-derived reactive oxygen species in NK cell-mediated control of murine melanoma metastasis. Cancer Immunol. Res. 2017, 5, 804-811. [CrossRef]

58. Kidd, M.E.; Shumaker, D.K.; Ridge, K.M. The role of vimentin intermediate filaments in the progression of lung cancer. Am. J. Respir. Cell Mol. Biol. 2014, 50, 1-6. [CrossRef]

59. Paccione, R.J.; Miyazaki, H.; Patel, V.; Waseem, A.; Gutkind, J.S.; Zehner, Z.E.; Yeudall, W.A. Keratin down-regulation in vimentin-positive cancer cells is reversible by vimentin RNA interference, which inhibits growth and motility. Mol. Cancer Ther. 2008, 7, 2894-2903. [CrossRef]

60. Lim, S.O.; Gu, J.M.; Kim, M.S.; Kim, H.S.; Park, Y.N.; Park, C.K.; Cho, J.W.; Park, Y.M.; Jung, G. Epigenetic changes induced by reactive oxygen species in hepatocellular carcinoma: Methylation of the E-cadherin promoter. Gastroenterology 2008, 135, 2128-2140. [CrossRef]

61. Senger, D.R.; Brown, L.F.; Claffey, K.P.; Dvorak, H.F. Vascular permeability factor, tumor angiogenesis and stroma generation. Invasion Metastasis 1994, 14, 385-394.

62. Ushio-Fukai, M.; Nakamura, Y. Reactive oxygen species and angiogenesis: NADPH oxidase as target for cancer therapy. Cancer Lett. 2008, 266, 37-52. [CrossRef] [PubMed]

63. de Sa Junior, P.L.; Camara, D.A.D.; Porcacchia, A.S.; Fonseca, P.M.M.; Jorge, S.D.; Araldi, R.P.; Ferreira, A.K. The Roles of ROS in Cancer Heterogeneity and Therapy. Oxid. Med. Cell. Longev. 2017. [CrossRef] [PubMed]

64. Schito, L. Hypoxia-Dependent Angiogenesis and Lymphangiogenesis in Cancer. Adv. Exp. Med. Biol. 2019, 1136, 71-85. [PubMed]

65. Dewhirst, M.W.; Cao, Y.; Moeller, B. Cycling hypoxia and free radicals regulate angiogenesis and radiotherapy response. Nat. Rev. Cancer 2008, 8, 425-437. [CrossRef]

66. Ushio-Fukai, M.; Alexander, R.W. Reactive oxygen species as mediators of angiogenesis signaling: Role of NAD(P)H oxidase. Mol. Cell. Biochem. 2004, 264, 85-97. [CrossRef] [PubMed]

67. Karar, J.; Maity, A. PI3K/AKT/mTOR Pathway in Angiogenesis. Front. Mol. Neurosci. 2011, 4. [CrossRef]

68. Rezatabar, S.; Karimian, A.; Rameshknia, V.; Parsian, H.; Majidinia, M.; Kopi, T.A.; Bishayee, A.; Sadeghinia, A.; Yousefi, M.; Monirialamdari, M.; et al. RAS/MAPK signaling functions in oxidative stress, DNA damage response and cancer progression. J. Cell. Physiol. 2019. [CrossRef] 
69. Khromova, N.V.; Kopnin, P.B.; Stepanova, E.V.; Agapova, L.S.; Kopnin, B.P. p53 hot-spot mutants increase tumor vascularization via ROS-mediated activation of the HIF1/VEGF-A pathway. Cancer Lett. 2009, 276, 143-151. [CrossRef]

70. Liu, Y.; Cui, Y.; Shi, M.; Zhang, Q.; Wang, Q.; Chen, X. Deferoxamine promotes MDA-MB-231 cell migration and invasion through increased ROS-dependent HIF-1alpha accumulation. Cell. Physiol. Biochem. 2014, 33, 1036-1046. [CrossRef]

71. Han, X.; Sun, S.; Zhao, M.; Cheng, X.; Chen, G.; Lin, S.; Guan, Y.; Yu, X. Celastrol stimulates hypoxia-inducible factor-1 activity in tumor cells by initiating the ROS/Akt/p70S6K signaling pathway and enhancing hypoxia-inducible factor-1alpha protein synthesis. PLoS One 2014, 9. [CrossRef]

72. Liu, L.Z.; Hu, X.W.; Xia, C.; He, J.; Zhou, Q.; Shi, X.; Fang, J.; Jiang, B.H. Reactive oxygen species regulate epidermal growth factor-induced vascular endothelial growth factor and hypoxia-inducible factor-1alpha expression through activation of AKT and P70S6K1 in human ovarian cancer cells. Free Radic. Biol. Med. 2006, 41, 1521-1533. [CrossRef] [PubMed]

73. Brewer, T.F.; Garcia, F.J.; Onak, C.S.; Carroll, K.S.; Chang, C.J. Chemical approaches to discovery and study of sources and targets of hydrogen peroxide redox signaling through NADPH oxidase proteins. Annu. Rev. Biochem. 2015, 84, 765-790. [CrossRef] [PubMed]

74. Xia, C.; Meng, Q.; Liu, L.Z.; Rojanasakul, Y.; Wang, X.R.; Jiang, B.H. Reactive oxygen species regulate angiogenesis and tumor growth through vascular endothelial growth factor. Cancer Res. 2007, 67, 10823-10830. [CrossRef] [PubMed]

75. Jin, F.; Wu, Z.; Hu, X.; Zhang, J.; Gao, Z.; Han, X.; Qin, J.; Li, C.; Wang, Y. The PI3K/Akt/GSK-3beta/ROS/eIF2B pathway promotes breast cancer growth and metastasis via suppression of NK cell cytotoxicity and tumor cell susceptibility. Cancer Biol. Med. 2019, 16, 38-54. [PubMed]

76. Govindarajan, B.; Sligh, J.E.; Vincent, B.J.; Li, M.; Canter, J.A.; Nickoloff, B.J.; Rodenburg, R.J.; Smeitink, J.A.; Oberley, L.; Zhang, Y.; et al. Overexpression of Akt converts radial growth melanoma to vertical growth melanoma. J. Clin. Invest. 2007, 117, 719-729. [CrossRef] [PubMed]

77. Giannoni, E.; Fiaschi, T.; Ramponi, G.; Chiarugi, P. Redox regulation of anoikis resistance of metastatic prostate cancer cells: Key role for Src and EGFR-mediated pro-survival signals. Oncogene 2009, 28, 2074-2086. [CrossRef]

78. Aydin, E.; Hallner, A.; Grauers Wiktorin, H.; Staffas, A.; Hellstrand, K.; Martner, A. NOX2 inhibition reduces oxidative stress and prolongs survival in murine KRAS-induced myeloproliferative disease. Oncogene 2019, 38, 1534-1543. [CrossRef]

79. Bino, L.; Vesela, I.; Papezikova, I.; Prochazkova, J.; Vasicek, O.; Stefkova, K.; Kucera, J.; Hanackova, M.; Kubala, L.; Pachernik, J. The depletion of p38alpha kinase upregulates NADPH oxidase 2/NOX2/gp91 expression and the production of superoxide in mouse embryonic stem cells. Arch. Biochem. Biophys. 2019, 671, 18-26. [CrossRef]

80. Komatsu, D.; Kato, M.; Nakayama, J.; Miyagawa, S.; Kamata, T. NADPH oxidase 1 plays a critical mediating role in oncogenic Ras-induced vascular endothelial growth factor expression. Oncogene 2008, 27, 4724-4732. [CrossRef]

81. De Bessa, T.C.; Pagano, A.; Moretti, A.I.S.; Oliveira, P.V.S.; Mendonca, S.A.; Kovacic, H.; Laurindo, F.R.M. Subverted regulation of Nox1 NADPH oxidase-dependent oxidant generation by protein disulfide isomerase A1 in colon carcinoma cells with overactivated KRas. Cell Death Dis. 2019, 10. [CrossRef]

82. Kim, Y.M.; Kim, K.E.; Koh, G.Y.; Ho, Y.S.; Lee, K.J. Hydrogen peroxide produced by angiopoietin-1 mediates angiogenesis. Cancer Res. 2006, 66, 6167-6174. [CrossRef] [PubMed]

83. Gupte, A.; Mumper, R.J. Elevated copper and oxidative stress in cancer cells as a target for cancer treatment. Cancer Treat. Rev. 2009, 35, 32-46. [CrossRef] [PubMed]

84. Rigiracciolo, D.C.; Scarpelli, A.; Lappano, R.; Pisano, A.; Santolla, M.F.; De Marco, P.; Cirillo, F.; Cappello, A.R.; Dolce, V.; Belfiore, A.; et al. Copper activates HIF-1alpha/GPER/VEGF signalling in cancer cells. Oncotarget 2015, 6, 34158-34177. [CrossRef] [PubMed]

85. Jing, Y.; Liu, L.Z.; Jiang, Y.; Zhu, Y.; Guo, N.L.; Barnett, J.; Rojanasakul, Y.; Agani, F.; Jiang, B.H. Cadmium increases HIF-1 and VEGF expression through ROS, ERK, and AKT signaling pathways and induces malignant transformation of human bronchial epithelial cells. Toxicol. Sci. 2012, 125, 10-19. [CrossRef] [PubMed] 
86. Coso, S.; Harrison, I.; Harrison, C.B.; Vinh, A.; Sobey, C.G.; Drummond, G.R.; Williams, E.D.; Selemidis, S. NADPH oxidases as regulators of tumor angiogenesis: Current and emerging concepts. Antioxid. Redox Signal. 2012, 16, 1229-1247. [CrossRef] [PubMed]

87. Sauer, H.; Wartenberg, M. Reactive oxygen species as signaling molecules in cardiovascular differentiation of embryonic stem cells and tumor-induced angiogenesis. Antioxid. Redox Signal. 2005, 7, 1423-1434. [CrossRef]

88. Harrison, I.P.; Vinh, A.; Johnson, I.R.D.; Luong, R.; Drummond, G.R.; Sobey, C.G.; Tiganis, T.; Williams, E.D.; JJ, O.L.; Brooks, D.A.; et al. NOX2 oxidase expressed in endosomes promotes cell proliferation and prostate tumour development. Oncotarget 2018, 9, 35378-35393. [CrossRef]

89. Mori, K.; Uchida, T.; Yoshie, T.; Mizote, Y.; Ishikawa, F.; Katsuyama, M.; Shibanuma, M. A mitochondrial ROS pathway controls matrix metalloproteinase 9 levels and invasive properties in RAS-activated cancer cells. FEBS J. 2019, 286, 459-478. [CrossRef]

90. Guo, D.; Wang, Q.; Li, C.; Wang, Y.; Chen, X. VEGF stimulated the angiogenesis by promoting the mitochondrial functions. Oncotarget 2017, 8, 77020-77027. [CrossRef]

91. Matsuda, S.; Nakagawa, Y.; Kitagishi, Y.; Nakanishi, A.; Murai, T. Reactive Oxygen Species, Superoxide Dimutases, and PTEN-p53-AKT-MDM2 Signaling Loop Network in Mesenchymal Stem/Stromal Cells Regulation. Cells 2018, 7, 36. [CrossRef]

92. Ma, L.; Fu, Q.; Xu, B.; Zhou, H.; Gao, J.; Shao, X.; Xiong, J.; Gu, Q.; Wen, S.; Li, F.; et al. Breast cancer-associated mitochondrial DNA haplogroup promotes neoplastic growth via ROS-mediated AKT activation. Int. J. Cancer 2018, 142, 1786-1796. [CrossRef] [PubMed]

93. Monteiro, H.P.; Rodrigues, E.G.; Amorim Reis, A.K.C.; Longo, L.S., Jr.; Ogata, F.T.; Moretti, A.I.S.; da Costa, P.E.; Teodoro, A.C.S.; Toledo, M.S.; Stern, A. Nitric oxide and interactions with reactive oxygen species in the development of melanoma, breast, and colon cancer: A redox signaling perspective. Nitric Oxide 2019, 89, 1-13. [CrossRef] [PubMed]

94. Zhou, X.; Yue, G.G.; Chan, A.M.; Tsui, S.K.; Fung, K.P.; Sun, H.; Pu, J.; Lau, C.B. Eriocalyxin B, a novel autophagy inducer, exerts anti-tumor activity through the suppression of Akt/mTOR/p70S6K signaling pathway in breast cancer. Biochem. Pharmacol. 2017, 142, 58-70. [CrossRef] [PubMed]

95. Khan, M.A.; Tania, M.; Zhang, D.Z.; Chen, H.C. Antioxidant enzymes and cancer. Chin. J. Cancer Res. 2010, 22, 87-92. [CrossRef]

96. Woo, C.C.; Hsu, A.; Kumar, A.P.; Sethi, G.; Tan, K.H.B. Thymoquinone inhibits tumor growth and induces apoptosis in a breast cancer xenograft mouse model: The role of p38 MAPK and ROS. PLoS ONE 2013, 8. [CrossRef]

97. Dai, X.; Wang, L.; Deivasigamni, A.; Looi, C.Y.; Karthikeyan, C.; Trivedi, P.; Chinnathambi, A.; Alharbi, S.A.; Arfuso, F.; Dharmarajan, A.; et al. A novel benzimidazole derivative, MBIC inhibits tumor growth and promotes apoptosis via activation of ROS-dependent JNK signaling pathway in hepatocellular carcinoma. Oncotarget 2017, 8, 12831-12842. [CrossRef]

98. Kim, C.; Lee, S.G.; Yang, W.M.; Arfuso, F.; Um, J.Y.; Kumar, A.P.; Bian, J.; Sethi, G.; Ahn, K.S. Formononetin-induced oxidative stress abrogates the activation of STAT3/5 signaling axis and suppresses the tumor growth in multiple myeloma preclinical model. Cancer Lett. 2018, 431, 123-141. [CrossRef]

99. Giorgio, M.; Migliaccio, E.; Orsini, F.; Paolucci, D.; Moroni, M.; Contursi, C.; Pelliccia, G.; Luzi, L.; Minucci, S.; Marcaccio, M.; et al. Electron transfer between cytochrome $\mathrm{c}$ and p66Shc generates reactive oxygen species that trigger mitochondrial apoptosis. Cell 2005, 122, 221-233. [CrossRef]

100. Danial, N.N.; Korsmeyer, S.J. Cell death: Critical control points. Cell 2004, 116, 205-219. [CrossRef]

101. Simon, H.-U.; Haj-Yehia, A.; Levi-Schaffer, F. Role of reactive oxygen species (ROS) in apoptosis induction. Apoptosis 2000, 5, 415-418. [CrossRef]

102. Redza-Dutordoir, M.; Averill-Bates, D.A. Activation of apoptosis signalling pathways by reactive oxygen species. Biochim. Biophys. Acta. 2016, 1863, 2977-2992. [CrossRef] [PubMed]

103. Giorgio, M.; Trinei, M.; Migliaccio, E.; Pelicci, P.G. Hydrogen peroxide: A metabolic by-product or a common mediator of ageing signals? Nat. Rev. Mol. Cell Biol. 2007, 8, 722-728. [CrossRef] [PubMed]

104. Park, K.R.; Nam, D.; Yun, H.M.; Lee, S.G.; Jang, H.J.; Sethi, G.; Cho, S.K.; Ahn, K.S. $\beta$-Caryophyllene oxide inhibits growth and induces apoptosis through the suppression of PI3K/AKT/mTOR/S6K1 pathways and ROS-mediated MAPKs activation. Cancer Lett. 2011, 312, 178-188. [CrossRef] [PubMed] 
105. Subramaniam, A.; Loo, S.Y.; Rajendran, P.; Manu, K.A.; Perumal, E.; Li, F.; Shanmugam, M.K.; Siveen, K.S.; Park, J.I.; Ahn, K.S.; et al. An anthraquinone derivative, emodin sensitizes hepatocellular carcinoma cells to TRAIL induced apoptosis through the induction of death receptors and downregulation of cell survival proteins. Apoptosis 2013, 18, 1175-1187. [CrossRef]

106. Lee, M.; Hirpara, J.L.; Eu, J.-Q.; Sethi, G.; Wang, L.; Goh, B.-C.; Wong, A.L. Targeting STAT3 and oxidative phosphorylation in oncogene-addicted tumors. Redox Biol. 2018. [CrossRef]

107. Deng, S.; Shanmugam, M.K.; Kumar, A.P.; Yap, C.T.; Sethi, G.; Bishayee, A. Targeting autophagy using natural compounds for cancer prevention and therapy. Cancer 2019, 125, 1228-1246. [CrossRef]

108. Liu, L.; Ahn, K.S.; Shanmugam, M.K.; Wang, H.; Shen, H.; Arfuso, F.; Chinnathambi, A.; Alharbi, S.A.; Chang, Y.; Sethi, G.; et al. Oleuropein induces apoptosis via abrogating NF- $\mathrm{KB}$ activation cascade in estrogen receptor-negative breast cancer cells. J. Cell. Biochem. 2019, 120, 4504-4513. [CrossRef]

109. Khan, M.A.; Chen, H.C.; Wan, X.X.; Tania, M.; Xu, A.H.; Chen, F.Z.; Zhang, D.Z. Regulatory effects of resveratrol on antioxidant enzymes: A mechanism of growth inhibition and apoptosis induction in cancer cells. Mol. Cells 2013, 35, 219-225. [CrossRef]

110. Hussain, A.R.; Ahmed, M.; Ahmed, S.; Manogaran, P.; Platanias, L.C.; Alvi, S.N.; Al-Kuraya, K.S.; Uddin, S. Thymoquinone suppresses growth and induces apoptosis via generation of reactive oxygen species in primary effusion lymphoma. Free Radic. Biol. Med. 2011, 50, 978-987. [CrossRef]

111. Dergarabetian, E.; Ghattass, K.; El-Sitt, S.; Al-Mismar, R.; El-Baba, C.; Itani, W.; Melhem, N.; El-Hajj, H.; Bazarbachi, A.; Schneider-Stock, R.; et al. Thymoquinone induces apoptosis in malignant T-cells via generation of ROS. Front. Biosci. 2013, 5, 706-719. [CrossRef]

112. Khan, M.A.; Tania, M.; Fu, S.; Fu, J. Thymoquinone, as an anticancer molecule: From basic research to clinical investigation. Oncotarget 2017, 8, 51907-51919. [CrossRef] [PubMed]

113. Mahmoud, Y.K.; Abdelrazek, H.M. Cancer: Thymoquinone antioxidant/pro-oxidant effect as potential anticancer remedy. Biomed. Pharmacother. 2019, 115. [CrossRef] [PubMed]

114. Li, F.; Shanmugam, M.K.; Chen, L.; Chatterjee, S.; Basha, J.; Kumar, A.P.; Kundu, T.K.; Sethi, G. Garcinol, a polyisoprenylated benzophenone modulates multiple proinflammatory signaling cascades leading to the suppression of growth and survival of head and neck carcinoma. Cancer Prev. Res. 2013, 6, 843-854. [CrossRef] [PubMed]

115. Sodrul, I.M.; Wang, C.; Chen, X.; Du, J.; Sun, H. Role of ginsenosides in reactive oxygen species-mediated anticancer therapy. Oncotarget 2018, 9, 2931-2950. [CrossRef] [PubMed]

116. Chakraborty, S.; Balan, M.; Flynn, E.; Zurakowski, D.; Choueiri, T.K.; Pal, S. Activation of c-Met in cancer cells mediates growth-promoting signals against oxidative stress through Nrf2-HO-1. Oncogenesis 2019, 8. [CrossRef] [PubMed]

117. Zhu, B.; Li, Y.; Lin, Z.; Zhao, M.; Xu, T.; Wang, C.; Deng, N. Silver nanoparticles induce HePG-2 cells apoptosis through ROS-mediated signaling pathways. Nanoscale Res. Lett. 2016, 11. [CrossRef]

118. An, B.C.; Choi, Y.D.; Oh, I.J.; Kim, J.H.; Park, J.I.; Lee, S.W. GPx3-mediated redox signaling arrests the cell cycle and acts as a tumor suppressor in lung cancer cell lines. PLoS One 2018, 13. [CrossRef]

119. Li, S.; Zhuang, Z.; Wu, T.; Lin, J.C.; Liu, Z.X.; Zhou, L.F.; Dai, T.; Lu, L.; Ju, H.Q. Nicotinamide nucleotide transhydrogenase-mediated redox homeostasis promotes tumor growth and metastasis in gastric cancer. Redox Biol. 2018, 18, 246-255. [CrossRef]

120. Kim, C.; Song, H.S.; Park, H.; Kim, B. Activation of ER stress-dependent miR-216b has a critical role in Salvia miltiorrhiza ethanol-extract-induced apoptosis in U266 and U937 cells. Int. J. Mol. Sci. 2018, 19, 1240. [CrossRef]

121. Yan, B.; Cheng, L.; Jiang, Z.; Chen, K.; Zhou, C.; Sun, L.; Cao, J.; Qian, W.; Li, J.; Shan, T.; et al. Resveratrol inhibits ROS-promoted activation and glycolysis of pancreatic stellate cells via suppression of miR-21. Oxid. Med. Cell. Longev. 2018, 2018. [CrossRef]

122. Kim, S.M.; Hur, D.Y.; Hong, S.W.; Kim, J.H. EBV-encoded EBNA1 regulates cell viability by modulating miR34a-NOX2-ROS signaling in gastric cancer cells. Biochem. Biophys. Res. Commun. 2017, 494, 550-555. [CrossRef] [PubMed]

123. Pradhan, A.K.; Bhoopathi, P.; Talukdar, S.; Scheunemann, D.; Sarkar, D.; Cavenee, W.K.; Das, S.K.; Emdad, L.; Fisher, P.B. MDA-7/IL-24 regulates the miRNA processing enzyme DICER through downregulation of MITF. Proc. Natl. Acad. Sci. USA 2019, 116, 5687-5692. [CrossRef] [PubMed] 
124. Zhou, Y.; Wang, Y.; Zhou, W.; Chen, T.; Wu, Q.; Chutturghoon, V.K.; Lin, B.; Geng, L.; Yang, Z.; Zhou, L.; et al. YAP promotes multi-drug resistance and inhibits autophagy-related cell death in hepatocellular carcinoma via the RAC1-ROS-mTOR pathway. Cancer Cell Int. 2019, 19. [CrossRef] [PubMed]

125. Hu, Y.; Zhang, H.; Dong, L.; Xu, M.; Zhang, L.; Ding, W.; Zhang, J.; Lin, J.; Zhang, Y.; Qiu, B.; et al. Enhancing tumor chemotherapy and overcoming drug resistance through autophagy mediated intracellular dissolution of zinc oxide nanoparticles. Nanoscale 2019, 11, 11789-11807. [CrossRef]

126. Hui, K.F.; Yeung, P.L.; Chiang, A.K. Induction of MAPK-and ROS-dependent autophagy and apoptosis in gastric carcinoma by combination of romidepsin and bortezomib. Oncotarget 2016, 7, 4454-4467. [CrossRef] [PubMed]

127. Scherz-Shouval, R.; Elazar, Z. Regulation of autophagy by ROS: Physiology and pathology. Trends Biochem. Sci. 2011, 36, 30-38. [CrossRef] [PubMed]

128. Scherz-Shouval, R.; Shvets, E.; Elazar, Z. Oxidation as a post-translational modification that regulates autophagy. Autophagy 2007, 3, 371-373. [CrossRef]

129. Ferro, F.; Servais, S.; Besson, P.; Roger, S.; Dumas, J.F.; Brisson, L. Autophagy and mitophagy in cancer metabolic remodelling. Semin. Cell Dev. Biol. 2019. [CrossRef]

130. Scherz-Shouval, R.; Elazar, Z. ROS, mitochondria and the regulation of autophagy. Trends Cell Biol. 2007, 17, 422-427. [CrossRef]

131. Ciccarone, F.; Castelli, S.; Ciriolo, M.R. Oxidative Stress-Driven Autophagy acROSs Onset and Therapeutic Outcome in Hepatocellular Carcinoma. Oxid. Med. Cell. Longev. 2019, 2019. [CrossRef]

132. Azad, M.B.; Chen, Y.; Gibson, S.B. Regulation of autophagy by reactive oxygen species (ROS): Implications for cancer progression and treatment. Antioxid. Redox Signal. 2009, 11, 777-790. [CrossRef] [PubMed]

133. Lim, S.D.; Sun, C.; Lambeth, J.D.; Marshall, F.; Amin, M.; Chung, L.; Petros, J.A.; Arnold, R.S. Increased Nox1 and hydrogen peroxide in prostate cancer. Prostate 2005, 62, 200-207. [CrossRef] [PubMed]

134. Ghavami, S.; Asoodeh, A.; Klonisch, T.; Halayko, A.J.; Kadkhoda, K.; Kroczak, T.J.; Gibson, S.B.; Booy, E.P.; Naderi-Manesh, H.; Los, M. Brevinin-2R1 semi-selectively kills cancer cells by a distinct mechanism, which involves the lysosomal-mitochondrial death pathway. J. Cell. Mol. Med. 2008, 12, 1005-1022. [CrossRef] [PubMed]

135. Cai, J.; Niu, X.; Chen, Y.; Hu, Q.; Shi, G.; Wu, H.; Wang, J.; Yi, J. Emodin-induced generation of reactive oxygen species inhibits RhoA activation to sensitize gastric carcinoma cells to anoikis. Neoplasia 2008, 10, 41-51. [CrossRef]

136. Poillet-Perez, L.; Despouy, G.; Delage-Mourroux, R.; Boyer-Guittaut, M. Interplay between ROS and autophagy in cancer cells, from tumor initiation to cancer therapy. Redox Biol. 2015, 4, 184-192. [CrossRef]

137. Rodríguez-Vargas, J.M.; Oliver-Pozo, F.J.; Dantzer, F. PARP1 and Poly (ADP-ribosyl) ation Signaling during Autophagy in Response to Nutrient Deprivation. Oxid. Med. Cell. Longev. 2019, 2019. [CrossRef]

138. Boyer-Guittaut, M.; Poillet, L.; Liang, Q.; Bôle-Richard, E.; Ouyang, X.; Benavides, G.A.; Chakrama, F.-Z.; Fraichard, A.; Darley-Usmar, V.M.; Despouy, G.; et al. The role of GABARAPL1/GEC1 in autophagic flux and mitochondrial quality control in MDA-MB-436 breast cancer cells. Autophagy 2014, 10, 986-1003. [CrossRef]

139. Lin, Y.; Jiang, M.; Chen, W.; Zhao, T.; Wei, Y. Cancer and ER stress: Mutual crosstalk between autophagy, oxidative stress and inflammatory response. Biomed. Pharmacother. 2019, 118. [CrossRef]

140. Kim, Y.-S.; Morgan, M.J.; Choksi, S.; Liu, Z.G. TNF-induced activation of the Nox1 NADPH oxidase and its role in the induction of necrotic cell death. Mol. Cell 2007, 26, 675-687. [CrossRef]

141. Li, L.; Tan, J.; Miao, Y.; Lei, P.; Zhang, Q. ROS and autophagy: Interactions and molecular regulatory mechanisms. Cell. Mol. Neurobiol. 2015, 35, 615-621. [CrossRef]

142. Li, X.; Chen, Y.; Zhao, J.; Shi, J.; Wang, M.; Qiu, S.; Hu, Y.; Xu, Y.; Cui, Y.; Liu, C. The specific inhibition of SOD1 selectively promotes apoptosis of cancer cells via regulation of the ROS signaling network. Oxid. Med. Cell. Longev. 2019. [CrossRef] [PubMed]

143. Neumann, C.A.; Fang, Q. Are peroxiredoxins tumor suppressors? Curr. Opin. Pharmacol. 2007, 7, 375-380. [CrossRef] [PubMed]

144. Ozben, T. Oxidative stress and apoptosis: Impact on cancer therapy. J. Pharm. Sci. 2007, 96, 2181-2196. [CrossRef] [PubMed]

145. Lin, Y.-H. MicroRNA Networks Modulate Oxidative Stress in Cancer. Int. J. Mol. Sci. 2019, $20,4497$. [CrossRef] 
146. Cadzow, M. Selection and Metabolic Disease in the Pacific. Ph.D. Thesis, University of Otago, Dunedin, New Zealand, 2018.

147. Glasauer, A.; Sena, L.A.; Diebold, L.P.; Mazar, A.P.; Chandel, N.S. Targeting SOD1 reduces experimental non-small-cell lung cancer. J. Clin. Invest. 2014, 124, 117-128. [CrossRef]

148. Gomez, M.; Germain, D. Cross talk between SOD1 and the mitochondrial UPR in cancer and neurodegeneration. Mol. Cell. Neurosci. 2019, 98, 12-18. [CrossRef]

149. Glasauer, A.; Chandel, N.S. Targeting antioxidants for cancer therapy. Biochem. Pharmacol. 2014, 92, 90-101. [CrossRef]

150. Mattes, K.; Vellenga, E.; Schepers, H. Differential redox-regulation and mitochondrial dynamics in normal and leukemic hematopoietic stem cells: A potential window for leukemia therapy. Crit. Rev. Oncol. Hematol. 2019, 144. [CrossRef]

151. Sánchez-Álvarez, M.; Strippoli, R.; Donadelli, M.; Bazhin, A.V.; Cordani, M. Sestrins as a Therapeutic Bridge between ROS and Autophagy in Cancer. Cancers 2019, 11, 1415. [CrossRef]

152. Yuan, X.; Wang, B.; Yang, L.; Zhang, Y. The role of ROS-induced autophagy in hepatocellular carcinoma. Clin. Res. Hepatol. Gastroenterol. 2018, 42, 306-312. [CrossRef]

153. Yang, H.; Villani, R.M.; Wang, H.; Simpson, M.J.; Roberts, M.S.; Tang, M.; Liang, X. The role of cellular reactive oxygen species in cancer chemotherapy. J. Exp. Clin. Cancer Res. 2018, 37. [CrossRef]

154. Ma, J.; Kavelaars, A.; Dougherty, P.M.; Heijnen, C.J. Beyond symptomatic relief for chemotherapy-induced peripheral neuropathy: Targeting the source. Cancer 2018, 124, 2289-2298. [CrossRef]

155. Bartolini, D.; Torquato, P.; Piroddi, M.; Galli, F. Targeting glutathione S-transferase P and its interactome with selenium compounds in cancer therapy. Biochim. Biophys. Acta. Gen. Subj. 2019, 1863, 130-143. [CrossRef]

156. Bansal, A.; Simon, M.C. Glutathione metabolism in cancer progression and treatment resistance. J. Cell Biol. 2018, 217, 2291-2298. [CrossRef]

157. Trachootham, D.; Zhou, Y.; Zhang, H.; Demizu, Y.; Chen, Z.; Pelicano, H.; Chiao, P.J.; Achanta, G.; Arlinghaus, R.B.; Liu, J. Selective killing of oncogenically transformed cells through a ROS-mediated mechanism by $\beta$-phenylethyl isothiocyanate. Cancer Cell 2006, 10, 241-252. [CrossRef]

158. Renschler, M.F. The emerging role of reactive oxygen species in cancer therapy. Eur. J. Cancer 2004, 40, 1934-1940. [CrossRef]

159. Gana, C.C.; Hanssen, K.M.; Denise, M.; Flemming, C.L.; Wheatley, M.S.; Conseil, G.; Cole, S.P.; Norris, M.D.; Haber, M.; Fletcher, J.I. MRP1 modulators synergize with buthionine sulfoximine to exploit collateral sensitivity and selectively kill MRP1-expressing cancer cells. Biochem. Pharmacol. 2019, 168, 237-248. [CrossRef]

160. Cilurzo, F.; Cristiano, M.; Da, M.P.; Quintieri, L.; Paolinod, D.; Pasut, G. Overcoming Cancer Cell Drug Resistance by a Folic Acid Targeted Polymeric Conjugate of Buthionine Sulfoximine. Anticancer Agents Med. Chem. 2019. [CrossRef]

161. Zhao, Y.; Tanaka, S.; Yuan, B.; Sugiyama, K.; Onda, K.; Kiyomi, A.; Takagi, N.; Sugiura, M.; Hirano, T. Arsenic Disulfide Combined with L-Buthionine-(S, R)-Sulfoximine Induces Synergistic Antitumor Effects in Two-Dimensional and Three-Dimensional Models of MCF-7 Breast Carcinoma Cells. Am. J. Chin. Med. 2019, 47, 1149-1170. [CrossRef]

162. Nazmeen, A.; Maiti, S. Oxidant stress induction and signalling in xenografted (human breast cancer-tissues) plus estradiol treated or N-ethyl-N-nitrosourea treated female rats via altered estrogen sulfotransferase (rSULT1E1) expressions and SOD1/catalase regulations. Mol. Biol. Rep. 2018, 45, 2571-2584. [CrossRef]

163. Mesbahi, Y.; Zekri, A.; Ghaffari, S.H.; Tabatabaie, P.S.; Ahmadian, S.; Ghavamzadeh, A. Blockade of JAK2/STAT3 intensifies the anti-tumor activity of arsenic trioxide in acute myeloid leukemia cells: Novel synergistic mechanism via the mediation of reactive oxygen species. Eur. J. Pharmacol. 2018, 834, 65-76. [CrossRef] [PubMed]

164. Sun, X.; Li, J.; Zhao, H.; Wang, Y.; Liu, J.; Shao, Y.; Xue, Y.; Xing, M. Synergistic effect of copper and arsenic upon oxidative stress, inflammation and autophagy alterations in brain tissues of Gallus gallus. J. Inorg. Biochem. 2018, 178, 54-62. [CrossRef] [PubMed]

165. Denoyer, D.; Pearson, H.B.; Clatworthy, S.A.; Smith, Z.M.; Francis, P.S.; Llanos, R.M.; Volitakis, I.; Phillips, W.A.; Meggyesy, P.M.; Masaldan, S.; et al. Copper as a target for prostate cancer therapeutics: Copper-ionophore pharmacology and altering systemic copper distribution. Oncotarget 2016, 7. [CrossRef] [PubMed] 
166. Cadavid-Vargas, J.F.; Leon, I.E.; Etcheverry, S.B.; Santi, E.; Torre, M.H.; Di Virgilio, A.L. Copper (II) complexes with saccharinate and glutamine as antitumor agents: Cytoand genotoxicity in human osteosarcoma cells. Anticancer Agents Med. Chem. 2017, 17, 424-433. [CrossRef]

167. Somwar, R.; Erdjument-Bromage, H.; Larsson, E.; Shum, D.; Lockwood, W.W.; Yang, G.; Sander, C.; Ouerfelli, O.; Tempst, P.J.; Djaballah, H.; et al. Superoxide dismutase 1 (SOD1) is a target for a small molecule identified in a screen for inhibitors of the growth of lung adenocarcinoma cell lines. Proc. Natl. Acad. Sci. USA 2011, 108, 16375-16380. [CrossRef]

168. Wang, Y.; Mandal, A.K.; Son, Y.-O.; Pratheeshkumar, P.; Wise, J.T.; Wang, L.; Zhang, Z.; Shi, X.; Chen, Z. Roles of ROS, Nrf2, and autophagy in cadmium-carcinogenesis and its prevention by sulforaphane. Toxicol. Appl. Pharmacol. 2018, 353, 23-30. [CrossRef]

169. Lee, J.H.; Khor, T.O.; Shu, L.; Su, Z.Y.; Fuentes, F.; Kong, A.-N.T. Dietary phytochemicals and cancer prevention: Nrf2 signaling, epigenetics, and cell death mechanisms in blocking cancer initiation and progression. Pharmacol. Ther. 2013, 137, 153-171. [CrossRef]

170. Zhang, J.; Li, X.; Han, X.; Liu, R.; Fang, J. Targeting the thioredoxin system for cancer therapy. Trends Pharmacol. Sci. 2017, 38, 794-808. [CrossRef]

171. Mohammadi, F.; Soltani, A.; Ghahremanloo, A.; Javid, H.; Hashemy, S.I. The thioredoxin system and cancer therapy: A review. Cancer. Chemother. Pharmacol. 2019,1-11. [CrossRef]

172. Benhar, M.; Shytaj, I.L.; Stamler, J.S.; Savarino, A. Dual targeting of the thioredoxin and glutathione systems in cancer and HIV. J. Clin. Invest. 2016, 126, 1630-1639. [CrossRef]

173. Thomas, S.R.; Khuntia, D. Motexafin gadolinium injection for the treatment of brain metastases in patients with non-small cell lung cancer. Int. J. Nanomedicine 2007, 2, 79-87. [CrossRef] [PubMed]

174. Evens, A.M. Motexafin gadolinium: A redox-active tumor selective agent for the treatment of cancer. Curr. Opin. Oncol. 2004, 16, 576-580. [CrossRef] [PubMed]

175. Ismail, T.; Kim, Y.; Lee, H.; Lee, D.S.; Lee, H.S. Interplay Between Mitochondrial Peroxiredoxins and ROS in Cancer Development and Progression. Int. J. Mol. Sci. 2019, 20, 4407. [CrossRef] [PubMed]

176. Chen, Y.F.; Liu, H.; Luo, X.J.; Zhao, Z.; Zou, Z.Y.; Li, J.; Lin, X.J.; Liang, Y. The roles of reactive oxygen species (ROS) and autophagy in the survival and death of leukemia cells. Crit. Rev. Oncol. Hematol. 2017, 112, 21-30. [CrossRef]

177. Zorov, D.B.; Juhaszova, M.; Sollott, S.J. Mitochondrial reactive oxygen species (ROS) and ROS-induced ROS release. Physiol. Rev. 2014, 94, 909-950. [CrossRef]

178. Ramaekers, B.L.; Riemsma, R.; Grimm, S.; Fayter, D.; Deshpande, S.; Armstrong, N.; Witlox, W.; Pouwels, X.; Duffy, S.; Worthy, G.; et al. Arsenic Trioxide for Treating Acute Promyelocytic Leukaemia: An Evidence Review Group Perspective of a NICE Single Technology Appraisal. Pharmacoeconomics 2019, 1-8. [CrossRef]

179. Yang, Y.; Karakhanova, S.; Hartwig, W.; D’Haese, J.G.; Philippov, P.P.; Werner, J.; Bazhin, A.V. Mitochondria and mitochondrial ROS in cancer: Novel targets for anticancer therapy. J. Cell. Physiol. 2016, 231, 2570-2581. [CrossRef]

180. Yokoyama, C.; Sueyoshi, Y.; Ema, M.; Mori, Y.; Takaishi, K.; Hisatomi, H. Induction of oxidative stress by anticancer drugs in the presence and absence of cells. Oncol. Lett. 2017, 14, 6066-6070. [CrossRef]

181. Horstman, M.G.; Meadows, G.G.; Yost, G.S. Separate mechanisms for procarbazine spermatotoxicity and anticancer activity. Cancer Res. 1987, 47, 1547-1550.

182. Skoetz, N.; Will, A.; Monsef, I.; Brillant, C.; Engert, A.; von Tresckow, B. Comparison of first-line chemotherapy including escalated BEACOPP versus chemotherapy including ABVD for people with early unfavourable or advanced stage Hodgkin lymphoma. Cochrane Database Syst. Rev. 2017. [CrossRef]

183. Donovan, L.E.; Lassman, A.B. Chemotherapy Treatment and Trials in Low-Grade Gliomas. Neurosurg. Clin. N. Am. 2019, 30, 103-109. [CrossRef] [PubMed]

184. Parasramka, S.; Talari, G.; Rosenfeld, M.; Guo, J.; Villano, J.L. Procarbazine, lomustine and vincristine for recurrent high-grade glioma. Cochrane Database Syst. Rev. 2017. [CrossRef]

185. Panchuk, R.R.; Skorokhyd, N.R.; Kozak, Y.S.; Lehka, L.V.; Moiseenok, A.G.; Stoika, R.S. Tissue-protective activity of selenomethionine and D-panthetine in B16 melanoma-bearing mice under doxorubicin treatment is not connected with their ROS scavenging potential. Croat. Med. J. 2017, 58, 171-184. [CrossRef] [PubMed]

186. Pilco-Ferreto, N.; Calaf, G.M. Influence of doxorubicin on apoptosis and oxidative stress in breast cancer cell lines. Int. J. Oncol. 2016, 49, 753-762. [CrossRef] [PubMed] 
187. Pillai, V.B.; Kanwal, A.; Fang, Y.H.; Sharp, W.W.; Samant, S.; Arbiser, J.; Gupta, M.P. Honokiol, an activator of Sirtuin-3 (SIRT3) preserves mitochondria and protects the heart from doxorubicin-induced cardiomyopathy in mice. Oncotarget 2017, 8. [CrossRef]

188. Megias-Vericat, J.; Montesinos, P.; Herrero, M.; Moscardo, F.; Boso, V.; Rojas, L.; Martínez-Cuadrón, D.; Rodríguez-Veiga, R.; Sendra, L.; Cervera, J.; et al. Impact of NADPH oxidase functional polymorphisms in acute myeloid leukemia induction chemotherapy. Pharmacogenomics J. 2018, 18. [CrossRef]

189. Platzbecker, U.; Avvisati, G.; Cicconi, L.; Thiede, C.; Paoloni, F.; Vignetti, M.; Ferrara, F.; Divona, M.; Albano, F.; Efficace, F.; et al. In Improved outcomes with retinoic acid and arsenic trioxide compared with retinoic acid and chemotherapy in non-high-risk acute promyelocytic leukemia: Final results of the randomized Italian-German APL0406 trial. J. Clin. Oncol. 2017, 35. [CrossRef]

190. Graczyk-Jarzynka, A.; Zagozdzon, R.; Muchowicz, A.; Siernicka, M.; Juszczynski, P.; Firczuk, M. New insights into redox homeostasis as a therapeutic target in B-cell malignancies. Curr. Opin. Hematol. 2017, 24. [CrossRef]

191. Trachootham, D.; Alexandre, J.; Huang, P. Targeting cancer cells by ROS-mediated mechanisms: A radical therapeutic approach? Nat. Rev. Drug Discov. 2009, 8, 579-591. [CrossRef]

192. Mazieres, J.; Barlesi, F.; Filleron, T.; Besse, B.; Monnet, I.; Beau-Faller, M.; Peters, S.; Dansin, E.; Früh, M.; Pless, M.; et al. Lung cancer patients with HER2 mutations treated with chemotherapy and HER2-targeted drugs: Results from the European EUHER2 cohort. Ann. Oncol. 2015, 27, 281-286. [CrossRef]

193. Li, X.; Wang, H.; Wang, J.; Chen, Y.; Yin, X.; Shi, G.; Li, H.; Hu, Z.; Liang, X. Emodin enhances cisplatin-induced cytotoxicity in human bladder cancer cells through ROS elevation and MRP1 downregulation. BMC Cancer 2016, 16. [CrossRef] [PubMed]

194. Ding, N.; Zhang, H.; Su, S.; Ding, Y.; Yu, X.; Tang, Y.; Wang, Q.; Liu, P. Emodin enhances the chemosensitivity of endometrial cancer by inhibiting ROS-mediated Cisplatin-resistance. Anticancer Agents Med. Chem. 2018, 18, 1054-1063. [CrossRef] [PubMed]

195. Garzon, R.; Marcucci, G.; Croce, C.M. Targeting microRNAs in cancer: Rationale, strategies and challenges. Nat. Rev. Drug Discov. 2010, 9, 775-789. [CrossRef] [PubMed]

196. Yang, Y.; Ishak Gabra, M.B.; Hanse, E.A.; Lowman, X.H.; Tran, T.Q.; Li, H.; Milman, N.; Liu, J.; Reid, M.A.; Locasale, J.W.; et al. MiR-135 suppresses glycolysis and promotes pancreatic cancer cell adaptation to metabolic stress by targeting phosphofructokinase-1. Nat. Commun. 2019, 10. [CrossRef] [PubMed]

197. Reid, M.A.; Wang, W.I.; Rosales, K.R.; Welliver, M.X.; Pan, M.; Kong, M. The B55alpha subunit of PP2A drives a p53-dependent metabolic adaptation to glutamine deprivation. Mol. Cell 2013, 50, 200-211. [CrossRef] [PubMed]

198. Li, Q.; Liu, X.; Yin, Y.; Zheng, J.T.; Jiang, C.F.; Wang, J.; Shen, H.; Li, C.Y.; Wang, M.; Liu, L.Z.; et al. Insulin regulates glucose consumption and lactate production through reactive oxygen species and pyruvate kinase M2. Oxid. Med. Cell Longev. 2014, 2014. [CrossRef]

199. Magenta, A.; Cencioni, C.; Fasanaro, P.; Zaccagnini, G.; Greco, S.; Sarra-Ferraris, G.; Antonini, A.; Martelli, F.; Capogrossi, M.C. miR-200c is upregulated by oxidative stress and induces endothelial cell apoptosis and senescence via ZEB1 inhibition. Cell Death Differ. 2011, 18, 1628-1639. [CrossRef]

200. Liu, Y.; Qiang, W.; Xu, X.; Dong, R.; Karst, A.M.; Liu, Z.; Kong, B.; Drapkin, R.I.; Wei, J.J. Role of miR-182 in response to oxidative stress in the cell fate of human fallopian tube epithelial cells. Oncotarget 2015, 6, 38983-38998. [CrossRef]

201. He, J.; Xu, Q.; Jing, Y.; Agani, F.; Qian, X.; Carpenter, R.; Li, Q.; Wang, X.R.; Peiper, S.S.; Lu, Z.; et al. Reactive oxygen species regulate ERBB2 and ERBB3 expression via miR-199a/125b and DNA methylation. EMBO Rep. 2012, 13, 1116-1122. [CrossRef]

202. Wu, Y.F.; Ou, C.C.; Chien, P.J.; Chang, H.Y.; Ko, J.L.; Wang, B.Y. Chidamide-induced ROS accumulation and miR-129-3p-dependent cell cycle arrest in non-small lung cancer cells. Phytomedicine 2019, 56, 94-102. [CrossRef]

203. Zhang, K.; Wu, L.; Zhang, P.; Luo, M.; Du, J.; Gao, T.; O'Connell, D.; Wang, G.; Wang, H.; Yang, Y. miR-9 regulates ferroptosis by targeting glutamic-oxaloacetic transaminase GOT1 in melanoma. Mol. Carcinog. 2018, 57, 1566-1576. [CrossRef] [PubMed]

204. Li, S.Z.; Hu, Y.Y.; Zhao, J.; Zhao, Y.B.; Sun, J.D.; Yang, Y.F.; Ji, C.C.; Liu, Z.B.; Cao, W.D.; Qu, Y.; et al. MicroRNA-34a induces apoptosis in the human glioma cell line, A172, through enhanced ROS production and NOX2 expression. Biochem. Biophys. Res. Commun. 2014, 444, 6-12. [CrossRef] [PubMed] 
205. Dworakowski, R.; Anilkumar, N.; Zhang, M.; Shah, A.M. Redox signalling involving NADPH oxidase-derived reactive oxygen species. Biochem. Soc. Trans. 2006, 34, 960-964. [CrossRef] [PubMed]

206. Weyemi, U.; Redon, C.E.; Parekh, P.R.; Dupuy, C.; Bonner, W.M. NADPH Oxidases NOXs and DUOXs as putative targets for cancer therapy. Anticancer Agents Med. Chem. 2013, 13, 502-514. [PubMed]

207. Liu, W.; Zabirnyk, O.; Wang, H.; Shiao, Y.H.; Nickerson, M.L.; Khalil, S.; Anderson, L.M.; Perantoni, A.O.; Phang, J.M. miR-23b targets proline oxidase, a novel tumor suppressor protein in renal cancer. Oncogene 2010, 29, 4914-4924. [CrossRef]

208. Liu, Y.; Borchert, G.L.; Surazynski, A.; Hu, C.A.; Phang, J.M. Proline oxidase activates both intrinsic and extrinsic pathways for apoptosis: The role of ROS/superoxides, NFAT and MEK/ERK signaling. Oncogene 2006, 25, 5640-5647. [CrossRef]

209. He, Z.; Li, Z.; Zhang, X.; Yin, K.; Wang, W.; Xu, Z.; Li, B.; Zhang, L.; Xu, J.; Sun, G.; et al. MiR-422a regulates cellular metabolism and malignancy by targeting pyruvate dehydrogenase kinase 2 in gastric cancer. Cell Death Dis. 2018, 9. [CrossRef]

210. Qu, J.; Zhang, L.; Li, L.; Su, Y. miR-148b Functions as a Tumor Suppressor by Targeting Endoplasmic Reticulum Metallo Protease 1 in Human Endometrial Cancer Cells. Oncol. Res. 2018, 27, 81-88. [CrossRef]

211. Kumari, S.; Badana, A.K.; Malla, R. Reactive oxygen species: A key constituent in cancer survival. Biomark. Insights 2018, 13. [CrossRef]

212. Raza, M.H.; Siraj, S.; Arshad, A.; Waheed, U.; Aldakheel, F.; Alduraywish, S.; Arshad, M. ROS-modulated therapeutic approaches in cancer treatment. J. Cancer Res. Clin. Oncol. 2017, 143, 1789-1809. [CrossRef]

213. Assi, M. The differential role of reactive oxygen species in early and late stages of cancer. Am. J. Physiol. Regul. Integr. Comp. Physiol. 2017, 313, R646-R653. [CrossRef] [PubMed]

214. Subramani, T.; Yeap, S.K.; Ho, W.Y.; Ho, C.L.; Omar, A.R.; Aziz, S.A.; Rahman, N.M.A.N.A.; Alitheen, N.B. Vitamin C suppresses cell death in MCF-7 human breast cancer cells induced by tamoxifen. J. Cell. Mol. Med. 2014, 18, 305-313. [CrossRef] [PubMed]

215. Alexandre, J.; Batteux, F.; Nicco, C.; Chéreau, C.; Laurent, A.; Guillevin, L.; Weill, B.; Goldwasser, F. Accumulation of hydrogen peroxide is an early and crucial step for paclitaxel-induced cancer cell death both in vitro and in vivo. Int. J. Cancer 2006, 119, 41-48. [CrossRef] [PubMed]

216. Fukui, M.; Yamabe, N.; Zhu, B.T. Resveratrol attenuates the anticancer efficacy of paclitaxel in human breast cancer cells invitro and in vivo. Eur. J. Cancer 2010, 46, 1882-1891. [CrossRef] [PubMed]

217. Diao, Q.; Zhang, J.; Zhao, T.; Xue, F.; Gao, F.; Ma, S.; Wang, Y. Vitamin E promotes breast cancer cell proliferation by reducing ROS production and p53 expression. Eur. Rev. Med. Pharmacol. Sci. 2016, 20, 2710-2717. [PubMed]

218. Podmore, I.D.; Griffiths, H.R.; Herbert, K.E.; Mistry, N.; Mistry, P.; Lunec, J. Vitamin C exhibits pro-oxidant properties. Nature 1998, 392, 559. [CrossRef]

219. Uetaki, M.; Tabata, S.; Nakasuka, F.; Soga, T.; Tomita, M. Metabolomic alterations in human cancer cells by vitamin C-induced oxidative stress. Sci. Rep. 2015, 5. [CrossRef]

220. Ahmad, A.; Syed, F.A.; Singh, S.; Hadi, S. Prooxidant activity of resveratrol in the presence of copper ions: Mutagenicity in plasmid DNA. Toxicol. lett. 2005, 159, 1-12. [CrossRef]

221. Khan, H.Y.; Zubair, H.; Faisal, M.; Ullah, M.F.; Farhan, M.; Sarkar, F.H.; Ahmad, A.; Hadi, S.M. Plant polyphenol induced cell death in human cancer cells involves mobilization of intracellular copper ions and reactive oxygen species generation: A mechanism for cancer chemopreventive action. Mol. Nutr. Food Res. 2014, 58, 437-446. [CrossRef]

(C) 2019 by the authors. Licensee MDPI, Basel, Switzerland. This article is an open access article distributed under the terms and conditions of the Creative Commons Attribution (CC BY) license (http://creativecommons.org/licenses/by/4.0/). 